\title{
DIREITO COMERCIAL OU DIREITO EMPRESARIAL? UMA ANÁLISE DA ADEQUABILIDADE DOS DESIGNATIVOS À LUZ DA EVOLUÇÃO HISTÓRICA DO IUS MERCATORUM
}

Renat Nureyev Mendes Jair Teixeira dos Reis Yury Vieira Tupynambá de Lélis Mendes Antonio Augusto Vilela

\section{RESUMO}

O presente trabalho tem por objetivo refletir sobre qual o designativo mais apropriado para o ramo do direito privado que não o direito comum (civil), isto é, se Direito Comercial ou se Direito Empresarial. Para tanto, lançou-se mão do método histórico, onde se buscou passear pela História do Comércio e do Direito Comercial (e Empresarial), de modo a justificar o melhor e mais apropriado uso. Ademais, a pesquisa bibliográfica foi importante recurso metodológico, como modo de verificar a visão dos jus-empresarialistas (doutrina) a respeito do tema em comento; como também o foi a pesquisa pautada na análise das grades curriculares dos cursos jurídicos, sob o recorte daqueles detentores do "Selo da OAB Re- 
comenda" (análise objetiva). A conclusão, assim, buscou se respaldar tanto em aspecto quantitativo, da tabulação auferida na pesquisa objetiva; quanto em aspecto qualitativo, oriundo de posição doutrinária mais consistente, sem, no entanto, se vincular a seus resultados quantitativos, senão apenas compreender o tratamento pelo qual se dá hodiernamente no Brasil a esse importante ramo da robusta árvore jurídica.

Palavras-chave: Direito Comercial e Empresarial. Designativos. Adequabilidade. Grades Curriculares. Jus-Empresarialistas.

\section{INTRODUÇÃO}

O objetivo do presente trabalho é refletir sobre qual a nomenclatura mais adequada, na atualidade (tendo em vista a conjuntura legislativa, didática e doutrinária coeva), para o ramo do Direito Privado, que não o Direito Civil: se Direito Comercial ou se Direito Empresarial. Para tanto, o uso do método histórico fez-se salutar, na medida em que se buscou passear pela História do Comércio e do Direito Comercial (e Empresarial), de modo a justificar o melhor e mais apropriado uso terminológico.

Na visão de Mamede ${ }^{79}$ é possível contar a história da humanidade sob a ótica do comércio e da empresa. Ao se vislumbrar a história sob estas lentes, pode-se, com efeito, depreender que "esforços individuais para auferir riqueza e benefícios pessoais acabaram beneficiando toda a humanidade, dando-lhe desenvolvimento e prosperidade, no amplo espaço do comércio e do mercado". E foi sob essa égide de que partiu o pressuposto das reflexões acerca do tema em tela, no presente trabalho.

De que se constata que, do surgimento do comércio (ou, mais cuidadamente, da elaboração de suas primeiras normas, ainda costumeiras) ao declínio da Teoria dos Atos do Comércio (Teoria germinada pelo Código Napoleônico), era corrente o uso da expressão Direito Comercial. Embora, no período antecedente ao predomínio da Teoria dos Atos de Comércio, notadamente quando da vigência da política econômica do Mercantilismo, fosse o termo Direito Mercantil de grande tradição. Ao que se pode observar a correspondência dos períodos do 1) Mercantilismo

\footnotetext{
79 MAMEDE, Gladston. Direito Empresarial brasileiro: empresa e atuação empresarial, volume 1. 7. ed. São Paulo: Atlas, 2013. p. 1.
} 
e do 2) Liberalismo Econômico e Individualista com a vigência dos Direitos 1) Mercantil e 2) Comercial, respectivamente.

Todavia, com a cunhagem, pela doutrina italiana germinada no Breve Século XX, da moderna Teoria da Empresa, fora o Direito Comercial substituído pelo Direito Empresarial?

Com a valorização da Empresa e da figura do empresário, incidida sobretudo com o advento dos novos códices que surgiram nos séculos XX e XXI (acolhendo a Teoria da Empresa), parte da doutrina passou a advogar que o termo Direito Empresarial seria o mais acertado para se designar tal ramo da árvore jurídica. No entanto, a expressão Direito Comercial, já mais tradicional e enraizada, nunca foi de todo esquecida; ao contrário, ainda suscita muitos defensores: sendo as figuras da Empresa e do Empresário apenas novas modalidades que, por mais abrangentes, deveriam ser incluídas no Direito Comercial.

Objetivando proporcionar mais acuradas reflexões acerca da problemática em comento, e de posse dos subsídios que a História do Comércio e do Direito Comercial proporcionam ao debate, a pesquisa bibliográfica será importante recurso metodológico, como modo de verificar a visão dos jus-empresarialistas (doutrina) a respeito do tema; como também o será pesquisa pautada na análise das matrizes curriculares dos cursos jurídicos (cujo resultado será exposto de modo didático e sequencial), sob o recorte daqueles detentores do "Selo OAB Recomenda" (análise objetiva). De modo que a conclusão possa se respaldar tanto em aspecto quantitativo, da tabulação auferida na pesquisa objetiva; quanto em aspecto qualitativo, oriundo de posição doutrinária mais consistente; sem, no entanto, se vincular a seus resultados quantitativos, senão apenas compreender o tratamento pelo qual se dá hodiernamente no Brasil a esse importante ramo da robusta árvore jurídica.

Sumularmente, o desenvolvimento do trabalho observará o seguinte esquema: i) "Evolução Histórica do Direito Comercial" (Do Surgimento do Comércio às Teorias dos Atos de Comércio e da Empresa); e ii) "Direito Comercial ou Direito Empresarial: a adequabilidade dos termos nos pensamentos dos jus-empresarialistas e nas grades curriculares dos cursos jurídicos no Brasil", que cuidará das reflexões acerca do designativo mais adequado à luz dos pensamentos dos "doutores" da ciência e da apuração dos resultados da pesquisa (quantitativa) das matrizes curriculares dos Cursos de Direito. 


\section{EVOLUÇÃO HISTÓRICA DO DIREITO COMERCIAL}

Importantes, como prolegômenos, são as palavras de Fazzio Júnior, para quem:

A Produção e a circulação de bens e serviços conheceram diversas etapas no processo de desenvolvimento humano. Seu estágio atual é o produto da crescente transformação das relações de produção, de um regime de plena subordinação do trabalho ao capital para um regime de condenação desses fatores básicos. ${ }^{80}$

Ao que se pode depreender que, o Direito Comercial, até chegar ao seu estágio atual, passou por diversas etapas na história, as quais contribuíram para a síntese em que hoje se encontra. É mister conhecer todas essas "fases".

Nesse ínterim, insta introduzir este estudo com breves apontamentos sobre a origem do comércio e o "desenvolvimento" do Direito Comercial, na História Geral e do Brasil.

\subsection{A origem e o desenvolvimento histórico do comércio}

Desde a Idade Antiga já existia o comércio ${ }^{81}{ }^{82}$, o que torna possível a afirmação de que "o comércio e o mercado são fenômenos humanos vitais" "83. Daí a importância em se conhecer a origem e o desenvolvimento histórico do comércio, vez que este já se fazia presente na vida e

80 FAZZIO JÚNIOR, Waldo. Manual de Direito Comercial. 8. ed. São Paulo: Atlas, 2007. p. 3.

81 "Não obstante ter existido o comércio desde a mais remota Antiguidade e, consequentemente, regras que o regulassem, não se deve inferir desde essa época, a existência do direito comercial, entendido como um conjunto ordenado e científico de regras destinadas a reger a prática do comércio. Este, como veremos, só surgirá embrionariamente na Idade Média, para se afirmar na Idade Moderna" (BULGARELLI, 1998, p. 25).

82 RAMOS, André Luiz Santa Cruz. Curso de Direito Empresarial: o novo regime jurídico-empresarial brasileiro. Salvador: JusPodivm, 2009.

83 MAMEDE, Gladston. Direito Empresarial brasileiro: empresa e atuação empresarial, volume 1. 7. ed. São Paulo: Atlas, 2013. p. 1. 
história humanas desde os tempos imemoriais - e, dificilmente, será ameaçado de extinção.

No entanto, o comércio não apareceu simultaneamente ao ser humano; houve, pois, um processo histórico que levou ao seu advento e, por conseguinte, ao seu desenvolvimento, até que se chegasse ao ponto de surgir normas para a sua regulação - normas estas que mais tarde se sistematizariam e se transformariam no que, atualmente, se conhece por Direito Comercial.

Mas, se por um lado o comércio não surgiu junto com o ser humano, por outro o trabalho ${ }^{84}$ é tão antigo quanto o próprio homem. São palavras de Reis:

O trabalho é tão antigo quanto o homem. Em todo o período da pré-história, o homem é conduzido, direta e amargamente, pela necessidade de satisfazer a fome e assegurar sua defesa pessoal. Ele caça, pesca e luta contra o meio físico, contra os animais e contra os seus semelhantes, tendo como instrumento as suas próprias mãos. ${ }^{85}$

Crê-se, com fulcro na arqueologia e na paleontologia, que os primeiros seres da espécie humana habitavam cavernas. Como esclarece Veloso (2001), estes humanos primitivos viviam do que a natureza lhes proporcionava, em um mesmo território: permanecendo, temporariamente, nessa determinada localidade, até que os mantimentos da redondeza viessem a se tornar escassos. Não mais encontrando o que comer, partiam em busca de alimentos em outros lugares.

$\mathrm{Na}$ mesma linha de pensamento, Mamede ${ }^{86}$ ratifica que, de fato, houve momentos na história "em que grupos humanos viveram o imediatismo da sobrevivência, buscando a cada instante os elementos necessários para manterem-se vivos".

84 Trabalho como o esforço físico e/ou intelectual com o objetivo de realizar alguma coisa, como quer Furquim (2001).

85 REIS, Jair Teixeira dos. História do Trabalho e seu conceito. In: Revista Eletrônica de Direito do Centro Universitário Newton Paiva, número 6, 2005.

${ }^{86}$ MAMEDE, Gladston. Direito Empresarial brasileiro: empresa e atuação empresarial, volume 1. 7. ed. São Paulo: Atlas, 2013. p. 1. 
Esses indivíduos (ou grupos humanos ${ }^{87}$ ) começaram a deixar a vida nômade a partir do advento da agricultura. Desde então, homens e mulheres encontraram uma forma de fugir do nomadismo, não tendo mais que ficar se deslocando de um lugar para outro em busca de alimentos. Nesse sentido comenta Veloso ${ }^{88}$ :

As mulheres ficavam na caverna cuidando dos afazeres domésticos, enquanto os homens saíam para buscar alimentos como milho, mandioca, frutas, verduras e toda espécie de grãos. O tempo fez com que as mulheres observassem que as sobras que caíam quando preparavam alimento, nasciam. Perceberam, as mulheres, que não havia a necessidade da vida nômade, pois poderiam plantar para colher. E, não, ficar procurando pela existência natural do que eles mesmos poderiam cultivar. Estava, assim, descoberta a agricultura. Feito atribuído às mulheres ${ }^{89}$. Tanto assim é verdade, que os gregos antigos deram à agricultura uma deusa. A deusa Ceres, como protetora da agricultura, gerou os atuais termos cereais, cerealista, etc.

Descoberta a agricultura, esta passa (juntamente com a criação de animais para corte), rapidamente, a fazer parte da vida dos indivíduos, de sobremaneira. Essa revolução agropecuária "instaura um tempo de previdência, de autocontrole e perseverança, tornando o ser humano um

87 O homem é um ser essencialmente social, com espírito associativo, razão pela qual indivíduos se agruparam e deram origem a agrupamentos humanos e, de suas relações de vizinhança, surgiram as cidades antigas, que é uma criação jurídica que se assenta num princípio de direito natural, sendo sua origem mais de ordem sociológica do que política. Superando sua fase nômade, alguns clãs sedentários definiram os primeiros aglomerados com base territorial, que se estendia até os limites da caça e da pesca e, depois, com o advento de novas técnicas, das pastagens para os rebanhos. Das relações de vizinhança com outros clãs, proveio o dinamismo dos limites territoriais, nascendo daí o Município, conforme os ensinamentos de Petrônio Braz (2006), com esteio em Fustel de Coulanges.

88 VELOSO, Waldir de Pinho. Essência do direito comercial. Montes Claros: Unimontes, 2001. p. 14.

89 Corrobora essa tese a universalidade da ligação entre a agricultura e as mulheres: Jair Teixeira dos Reis (2005), sobre os costumes indígenas brasileiros, disserta sobre a dificuldade de dispêndio de força de trabalho indígena para o cultivo, vez que, "de acordo com a cultura deles, plantar e colher eram atividades femininas". 
sócio ativo da natureza, em vez de continuar como parasita, além de exigir uma divisão de trabalho"..$^{90}$

Com o sedentarismo, os humanos passaram a cultivar para a sobrevivência. Eles, já estabelecidos e fixos, plantavam apenas as sementes já encontradas naturalmente na região. Com a "ramificação" das "famílias", através dos casamentos, surgem novas convenções sociais, tais como as visitas e a cultura do presentear. Assim,

com os casamentos e as mudanças de elementos da família para locais considerados distantes, em certas visitas, uns levavam alimentos que produziam como presentes. Também nesses novos locais o que ia, voluntária ou involuntariamente, para o lixo nascia e começava uma produção desconhecida no local. ${ }^{91}$

Mais uma vez, o tempo foi um aliado fundamental na história dos homens, pois fez com que "entendessem que a troca era importante, para variar a produção agrícola. E passaram a ter o escambo como atividade normal. Não se tratava mais de presente, mas de forma de melhor sobrevivência". ${ }^{92}$

Ou seja, na antiguidade, roupas e víveres eram produzidos na própria casa, para seus moradores; no entanto, os excedentes eventuais eram trocados entre vizinhos ou na praça ${ }^{93}$, ou ainda entre familiares, como apregoa Veloso (2001), já supracitado.

Houve um momento em que essa troca interfamiliar (e também a entre "vizinhos") foi se transformando e passou a ter um caráter profissional, "passando as famílias a procurarem por desconhecidos, com a intenção de trocar o que lhes sobravam de suas produções". ${ }^{94}$

Corrobora Mamede:

\footnotetext{
${ }^{90}$ MAMEDE, Gladston. Direito Empresarial brasileiro: empresa e atuação empresarial, volume 1. 7. ed. São Paulo: Atlas, 2013. p. 3.

91 VELOSO, Waldir de Pinho. Essência do direito comercial. Montes Claros: Unimontes, 2001. p. 14.

92 Idem. p. 14-15.

93 COELHO, Fábio Ulhoa. Manual de Direito Comercial: Direito de Empresa. São Paulo: Saraiva, 2010.

94 VELOSO, Waldir de Pinho. Essência do direito comercial. Montes Claros: Unimontes, 2001. p. 15.
} 
A produção de excedentes e a capacidade de armazená-los foi o vetor de superação dos limites da mera subsistência, viabilizando a formação de conglomerados organizados de pessoas - as cidades -, cuja estrutura evoluída é o Estado, inicialmente manifestado sob a forma de Cidade-Estado..$^{95}$

Superada a utilização do comércio somente como meio de subsistência, começou-se a buscar possibilidades para se melhor aproveitá-lo. Sobre o surgimento da moeda (criação de grande contribuição para o desenvolvimento do comércio), doutrina Veloso:

O alvo era o que as famílias distintas tinham no ato para repor. Como nem sempre a troca era prontamente atendida, a parte credora começou a receber símbolos que representavam um crédito para posterior cumprimento. Os protótipos das atuais moedas foram conchas do mar e as pedras. Representavam um crédito equivalente a certas quantidades de determinados produtos, por mera convenção entre as partes. ${ }^{96}$

A partir de Veloso, portanto, pode-se inferir que as primeiras moedas cunhadas representavam os créditos entre famílias, regiões e civilizações. Dessa feita, "havia, pois, uma necessidade de um centro de troca dessas moedas. Nasceu, nessas épocas, o sistema de colocar bancas com exposição das moedas que o banqueiro tinha disponível para o câmbio". ${ }^{97}$

Sobre o surgimento e desenvolvimento dos bancos, é elucidativo:

Nem sempre quem tinha uma moeda precisava do retorno imediato. E esses abastados (porque tinham mais do que o suficiente para a sobrevivência) passaram a deixar nas bancas as suas moedas, nas

\footnotetext{
95 MAMEDE, Gladston. Direito Empresarial brasileiro: empresa e atuação empresarial, volume 1. 7. ed. São Paulo: Atlas, 2013. p. 3.

96 VELOSO, Waldir de Pinho. Essência do direito comercial. Montes Claros: Unimontes, 2001. p. 15.

${ }^{97}$ Ibidem.
} 
cidades, enquanto faziam negócios com outros. Ao celebrarem um negócio, enviavam um bilhete contendo uma ordem para que o banqueiro entregasse, do seu crédito, ao portador, uma certa quantia, a ser abatida do total ali depositado. Tudo equivale ao que hoje se conhece por banco, contacorrente, cheque, ordem de pagamento, depósito, câmbio e outros elementos que fazem o dia a dia da atividade bancária. Inclusive quanto ao nome: de banca, para banco. ${ }^{98}$

Acontecia, de quando em vez, do dono da banca administrar mal os negócios e não ter condições de cumprir com seus compromissos; ou seja, por vezes ele não conseguia honrar a entrega dos valores com ele depositados. Ocorrendo isso,

era direito de o credor comparecer, em público, e quebrar, aos murros, a banquinha de madeira onde era expostas as moedas para troca. Diziam que a banca estava rota, podre. Surgiram expressões 'bancarrotas', 'quebra', 'quebradeira' e outros, hoje sinônimas de falência. ${ }^{99}$

Nesse sentido, "com as primeiras quebras de bancas, notou-se que a fidúcia, a confiança no depositário, era dos mais importantes pontos a serem observados" 100 , acarretando que, para solucionar esse problema,

a escolha passou a recair em pessoas estabelecidas que detinham condições financeiras superiores ao que um tabuleiro de madeira, com pernas, representava. A figura do comerciante estava sendo desenhada neste momento. $O$ suporte de um patrimônio mínimo como garantia da confiança

98 VELOSO, Waldir de Pinho. Essência do direito comercial. Montes Claros: Unimontes, 2001. p. 16.

${ }^{99}$ Ibidem.

100 Ibidem. 
gerou a organização empresarial em seus primeiros passos. ${ }^{101}$

Em seguida, "a atividade comercial continuou com o depósito, nas cidades, em mãos de comerciantes que centralizavam a troca da sobra de produção de uma família ou região, por produtos em sobra ou disponíveis de outras famílias ou regiões"102. Em síntese, "o comércio nasce pelo escambo, pela troca de necessidades". ${ }^{103}$

Portanto, "percebe-se assim que, desde o nascedouro, o comércio é a atividade humana que faz com que haja a circulação da produção. Gera, distribui e dissemina a riqueza, descentralizando o consumo independentemente da sua área de origem". ${ }^{104}$

Assim, "não se limitando a troca ou câmbio de dinheiro, mas também de todos os produtos disponíveis, sempre coube à atividade comercial a função de levar além das fronteiras dos locais da produção, o resultado do trabalho humano". ${ }^{105}$

De todo o exposto, depreende-se que o comércio, nesse período, tinha um duplo escopo: tanto o de 1) facilitar a vida dos indivíduos (seja oportunizando com que pudessem deixar de se locomoverem peregrinamente; seja por permitir que passassem a ter mais do que precisavam, tendo, dessa forma, uma certa tranquilidade em relação ao futuro), como o de 2) aproximá-los.

Em resumo, vital é a importância do comércio, pois mais do que a troca, o comércio é outrossim aproximação, conforme Veloso ${ }^{106}$, com fulcro em Say.

\subsection{A "evolução" do Direito Comercial na história geral}

\footnotetext{
101 VELOSO, Waldir de Pinho. Essência do direito comercial. Montes Claros: Unimontes, 2001. p. 16.

102 Ibidem.

${ }^{103}$ MAMEDE, Gladston. Direito Empresarial brasileiro: empresa e atuação empresarial, volume 1. 7. ed. São Paulo: Atlas, 2013. p. 4.

104 VELOSO, Waldir de Pinho. Essência do direito comercial. Montes Claros: Unimontes, 2001. p. 16.

105 Idem. p. 17.

106 Ibidem.
} 
Mesmo na Antiguidade, como não poderia deixar de ser,

já existiam institutos pertinentes ao Direito Comercial, como o empréstimo a juros e os contratos de sociedade, de depósito e de comissão no Código de Hamurabi, ou o empréstimo a risco (nauticum foenus) na Grécia antiga, ou a avaria grossa da Lex Rhodia de jactu, dos romanos. ${ }^{107}$

Pois, como ensina Reis, amparado pelas lições de Russomano,

a importância econômica, social e ética do trabalho não passou desapercebida dos legisladores antigos. No Código de Manu há normas sobre a empresa, na forma rudimentar com que ela se havia constituído. Os historiadores mais credenciados da Antiguidade aludem às organizações de classes dos hindus, dos árias, dos egípcios. Toda a preocupação parecia reduzir-se à organização social das classes, entre estas a dos trabalhadores, para conservá-los no círculo do seu destino. ${ }^{108}$

Com o desenvolvimento do comércio, surgiu a necessidade de criar normas para regulamentar todo aquele processo: daí o Direito Comercial. Do período pré-romano à atualidade, pode-se perceber um interesse em organizar esse fenômeno que nascia e não mais morreria. $\mathrm{Na}$ verdade,

pelo que consta, as primeiras regulamentações, ainda que primitivas e assistemáticas, das atividades econômicas foram encontradas no Código de Manu (Índia) e no Código de Hamurabi, esculpidos entre

107 FÜHRER, Maximilianus Cláudio Américo. Resumo de Direito Comercial. São Paulo: Malheiros Editores, 2004. p. 13.

108 REIS, Jair Teixeira dos. História do Trabalho e seu conceito. In: Revista Eletrônica de Direito do Centro Universitário Newton Paiva, número 6, 2005. 
1850 e 1750 a.C., sendo considerados as primeiras 'codificações' do direito comercial. ${ }^{109}$

Tratando-se de Direito Comercial (e de sua evolução histórica), diz-se que ele perpassou pela época pré-romana (com os assírios, os babilônios e os gregos, principalmente), todavia, sem contribuições diretas para o desenvolvimento posterior da matéria. Por sua vez,

Roma não cuidou especificamente de um direito especial do comércio, contentando-se com algumas normas fragmentadas para regular certas relações comerciais, mesmo porque o comércio era exercido por meio dos escravos. ${ }^{110}$

Ou seja, em Roma, "as regras comerciais específicas faziam parte do direito comum, do direito civil". ${ }^{111}$

Dessa forma, foi só na Idade Média que "a evolução do comércio, a partir da eclosão das cidades medievais e da burguesia, [revelou] um inegável e natural paralelismo com a do Direito Comercial". ${ }^{12}$ Nesse período, "pode-se perceber o surgimento do Direito Comercial como um direito autônomo, tendo na Itália seu maior berço e propagação, centrando-se o tráfego mundial no mediterrâneo". ${ }^{113}$

Durante a Idade Média, "o comércio já atingira um estágio mais avançado, e não era mais uma característica de apenas alguns povos, mas de todos eles". ${ }^{114}$ Neste época, de acordo com Ramos,

\footnotetext{
109 ARNOULDI, Paulo Roberto Colombo. Teoria Geral do Direito Comercial: introdução à teoria da empresa. São Paulo: Saraiva, 1998. p. 1.

${ }^{110}$ FERNANDES, Jean Carlos. Direito Empresarial Aplicado. Belo Horizonte: Del Rey, 2007. p. 3.

111 RAMOS, André Luiz Santa Cruz. Curso de Direito Empresarial: o novo regime jurídico-empresarial brasileiro. Salvador: JusPodivm, 2009. p. 28.

112 FAZZIO JÚNIOR, Waldo. Manual de Direito Comercial. 8. ed. São Paulo: Atlas, 2007. p. 3.

113 FERNANDES, Jean Carlos. Direito Empresarial Aplicado. Belo Horizonte: Del Rey, 2007. p. 3.

114 RAMOS, André Luiz Santa Cruz. Curso de Direito Empresarial: o novo regime jurídico-empresarial brasileiro. Salvador: JusPodivm, 2009. p. 28.
} 
não havia ainda um poder político central forte, capaz de impor regras gerais e aplicá-las a todos. $\mathrm{O}$ poder político era altamente descentralizado, o que fez surgir uma série de 'direitos locais' nas diversas regiões da Europa. Em contrapartida, ganhava força o Direito Canônico, que repudiava o lucro e não atendia, portanto, aos interesses da classe burguesa que se formava e ganhava força. Essa classe burguesa, os chamados comerciantes ou mercadores, tiveram então que se organizar e construir o seu próprio 'direito', a ser aplicado nos diversos conflitos que passaram a eclodir com a efervescência da atividade mercantil que se observava, após décadas de estagnação do comércio. As regras do direito comercial foram surgindo, pois, da própria dinâmica da atividade negocial. ${ }^{115}$

Destarte, da segunda metade do século XII às últimas décadas do século XVI, artesãos e mercadores (que faziam parte da crescente burguesia) resolveram se unir, de modo a cunharem normas mercantis para solução de conflitos.

Para isso, foram criadas as Corporações de Ofício, que nada mais eram do que Associações, de mercadores e artesãos, que tinham como fito dirimir quaisquer conflitos de interesses entre seus membros, pois só sofriam a incidência das normas quem participasse daquela classe. Daí o caráter subjetivista desta fase da evolução histórica do Direito Comercial.

As Corporações de Ofício "logo assumiram relevante papel na sociedade da época, conseguindo obter, inclusive, uma certa autonomia em relação à nobreza feudal" $116 .{ }^{117}$ Deveras, "com o incremento do comércio, fortaleceram-se os grupos profissionais dos mercadores, chamados de

115 RAMOS, André Luiz Santa Cruz. Curso de Direito Empresarial: o novo regime jurídico-empresarial brasileiro. Salvador: JusPodivm, 2009. p. 28.

${ }^{116}$ Idem. p. 29.

117 A esse respeito, trata muito bem Leo Huberman, em seu "A História da Riqueza do Homem". 
corporações de ofício. Bem organizadas, as corporações passaram a tutelar os interesses de seus membros em face da impotência do Estado". ${ }^{118}$

Como era a própria Corporação (enquanto coadunação de seus membros) que criava as normas, e no mais das vezes os "legisladores mercantis" não eram detentores dos necessários conhecimentos técnicos e jurídicos, a grande fonte dessas regras não poderiam deixar de ser, portanto, os costumes da época.

Em outras palavras, "os comerciantes, assim, passaram a se reunir em associações ou corporações, que conservavam sua autonomia própria para dirimir, com base no direito consuetudinário, as demandas envolvendo a atividade comercial". ${ }^{119}$

Efetivamente,

as corporações de mercadores da Idade Média constituíram-se no órgão primário de desenvolvimento do Direito Comercial como um direito especial e autônomo, destacando-se, sem dúvida alguma, a Itália como o seu local de nascimento a partir da criação espontânea da prática comercial. ${ }^{120}$

Em um momento posterior, que vai do final do século XVI até às últimas décadas do século XVIII, pode-se falar em uma outra fase da evolução histórica do Direito Comercial, que coincide com o surgimento dos Estados Nacionais. Nessa fase é crescente o mercantilismo ${ }^{121}$; e o mercado, que até então se concentrava na "Itália", acaba por espalhar-se para a Holanda, França e Inglaterra, entre outros países europeus.

Esse período do surgimento dos Estados Nacionais, coincidente com o mercantilismo,

${ }^{118}$ RODRIGUES, Frederico Viana. Autonomia do Direito de Empresa no Novo Código Civil. In: RODRIGUES, Frederico Viana (Org.). Direito de Empresa no Novo Código Civil. Rio de Janeiro: Forense, 2004. p. 17.

${ }^{119}$ FERNANDES, Jean Carlos. Direito Empresarial Aplicado. Belo Horizonte: Del Rey, 2007. p. 4.

${ }^{120}$ Ibidem.

${ }^{121}$ Mercantilismo foi o conjunto de práticas econômicas adotadas, entre os séculos XV e XVIII, pelos Estados Nacionais europeus. O Mercantilismo caracterizou-se pela forte intervenção estatal na Economia. 
caracteriza-se pela expansão colonial e é a época áurea da evolução das grandes sociedades, sempre sob a autorização do Estado. Vige a regra: 'as associações são lícitas, desde que o Rei as autorize'. As normas de Direito Comercial, como as demais, são emanadas de um poder soberano central. Surgem [desta forma] codificações em toda a Europa. ${ }^{122}$

Nesse diapasão, com o surgimento dos Estados Nacionais buscou-se o seu fortalecimento. Para tanto, era mister que o Direito deixasse de ser consuetudinário para se tornar um Direito editado pelo próprio Estado. Em outros termos, nesse momento, a jurisdição mercantil deixa de ser privada e passa a ser estatal.

Ocorreu, nos então coevos Estados Nacionais, a uniformização das normas jurídicas, pois, nesse instante, começaram relacionamentos mercantis e comerciais entre os "países". Nesse período, portanto, "é grande o desenvolvimento de novas e rendosas redes comerciais". ${ }^{123}$

No século XIX, mais precisamente em 1807, o Código Comercial de Napoleão inaugura uma outra fase histórica do Direito Comercial. Com o objetivo de abolir o corporativismo, a Codificação Napoleônica adota a Teoria dos Atos de Comércio: lega-a ao mundo. Fernandes confirma essa mudança de panorama, quando afirma que:

A objetivação do caráter do Direito Comercial foi desencadeada pelo Código de Comércio francês de 1807 (Código de Napoleão), que marcou época de comércio na evolução histórica de tal ramo do direito como o primeiro ensaio de uma codificação completa da matéria. Assim, o Direito Comercial deixou de ser o direito dos comerciantes e passou a ser o direito dos atos de comércio, os quais, praticados por quem quer que fosse, estavam sujeitos às leis e ao juízo comercial. ${ }^{124}$

\footnotetext{
122 NEGRÃO, Ricardo. Manual de Direito Comercial e de Empresa. 10. ed. São Paulo: Saraiva, 2013. p. 32.

${ }^{123}$ Ibidem.

${ }^{124}$ FERNANDES, Jean Carlos. Direito Empresarial Aplicado. Belo Horizonte: Del Rey, 2007. p. 5.
} 
Nesse contexto, o Direito Comercial passou a ter um caráter objetivista, pois não dependia mais de quem fazia parte de um grupo de mercadores, "inscritos" em uma Corporação privada, e sim de que atos (de comércio) eram praticados. Sobre essa transição do Direito dos Comerciantes para o Direito do Comércio, comenta Carvalho de Mendonça:

Era natural que, com o desenvolvimento ulterior, surgisse o conceito de ato de comércio, o que, de certo, vem a pôr em foco a objetivação do Direito Comercial, que, ao invés do direito profissional dos comerciantes, passou a ser o direito do comércio. ${ }^{125}$

Já no século XX, em 1942, surge, no Reino da Itália (sob o regime fascista, do Premier Benito Mussolini, Il Duce do Partito Nazionale Fascista),

um novo sistema de regulação das atividades econômicas dos particulares. Nele, alarga-se o âmbito de incidência do Direito Comercial, passando as atividades de prestação de serviços e ligadas à terra a se submeterem às mesmas normas aplicáveis às comerciais, bancárias, securitárias e industriais. Chamou-se o novo sistema de disciplina das atividades privadas de teoria da empresa. O Direito Comercial, em sua terceira etapa evolutiva, deixa de cuidar de determinadas atividades (as de mercancia) e passa a disciplinar uma forma específica de produzir ou circular bens ou serviços, a empresarial. 126

Voltando um pouco no tempo, no início do século XX, o jurista italiano Cesare Vivante, professor da Universidade de Bolonha, alegando que tanto o direito comercial quanto o direito civil eram ambos partes do direito privado, difícil era se fazer nítida separação entre as matérias reguladas por um ou outro, sobretudo devido ao alargamento do conteúdo do

\footnotetext{
125 MENDONÇA, Jacy de Souza. Introdução ao Estudo do Direito. São Paulo: Rideel, 2010. p. 71.

126 COELHO, Fábio Ulhoa. Manual de Direito Comercial: Direito de Empresa. São Paulo: Saraiva, 2010. p. 8.
} 
direito comercial que se processava, dado o aparecimento de novas formas econômicas. Para ele, essa divisão do direito privado em civil e comercial só se sustentava devido à origem histórica dos dois ramos e ao seu caráter didático.

E é a Teoria da Empresa, cunhada por Cesare Vivante, que põe termo à dicotomia entre os direitos civil e comercial (empresarial), à medida que deixa de vincular o empresário ao exercício da mercancia, para atrelá-lo ao desenvolvimento da empresa, como uma forma de suprimir a sujeição dos consumidores às leis mercantis, bem como as inúteis discussões sobre a natureza dos foros e normas competentes para as referidas questões.

De lado outro, o também jurista italiano Alfredo Rocco rebateu os argumentos de Vivante, fundamentando-se principalmente no conteúdo próprio do direito comercial. Em seu entendimento, há duas espécies de normas de direito comercial: 1) as normas que, mesmo derivando da legislação civil, ganham contorno especial face às relações comerciais; e 2) normas totalmente novas, decorrentes de relações comerciais que não encontram correlação nas relações civis. E, argumentando a diferença de tratamento da primeira espécie de normas, bem como o tratamento completamente novo dado à segunda espécie de normas, Alfredo Rocco extrai o conteúdo do Direito Comercial, o que impede a unificação dos dois ramos do direito privado. É que a ética empresarial e a ética civil são diferentes, reclamando cada qual regulamento próprio. Mas, nem por isso, Alfredo Rocco descarta o direito civil como fonte do direito comercial, muito pelo contrário: aquele deve ser usado para suprir as lacunas deste, como também os costumes e os princípios gerais de direito.

Após intenso embate acadêmico entre os dois, Cesare Vivante se retratou, em 1919, abrindo mão de seu posicionamento e afirmando a impossibilidade da unificação das obrigações dos dois ramos, estando convencido da necessidade da autonomia do Direito Civil e do Direito Comercial. Ele chegou inclusive a ser nomeado para presidir comissão de elaboração de projeto para um novo código comercial para a Itália, que não chegou a ser concluído.

Porém, com o advento do Partito Nazionale Fascista ao governo italiano, este promulgou, em 1942, o novo diploma civil daquele país, que unificou num só corpo legislativo as matérias dos dois ramos do direito privado. Isso, devido à conveniência da adoção desta teoria para a consecução de seus objetivos políticos ideológicos. Tanto é assim que 
Coelho ${ }^{127}$ chama a atenção para o local e ano em que a teoria da empresa se expressou pela primeira vez no ordenamento positivo: "O mundo estava em guerra e, na Itália, governava o ditador fascista Mussolini”.

É que o Fascismo, embora doutrina vermelha, discordava em vários pontos do marxismo, pretendendo superar e pôr fim à luta de classes por meio da organização sindicalista, "agrupando nas mesmas corporações todos os membros de cada ramo da produção, sem distinção entre patrões e operários. Esse corporativismo mussoliano lançava suas raízes nas antigas corporações medievais e seguia, particularmente, a teoria de Georges Sorel"128, de quem Mussolini se dizia discípulo.

A ideologia fascista não é tão sofisticada como a comunista, mas um pequeno paralelo entre ela e o marxismo ajuda a entender a ambientação política do surgimento da teoria da empresa. Para essas duas concepções ideológicas, burguesia e proletariado estão em luta; elas divergem sobre como a luta terminará. Para o marxismo, o proletariado tomará o poder do estado, expropriará das mãos da burguesia os bens de produção e porão fim às classes sociais (e, em seguida, ao próprio estado), reorganizando-se as relações de produção.

Já para o fascismo, a luta de classes termina em harmonização patrocinada pelo estado nacional. Burguesia e proletariado superam seus antagonismos na medida em que se unem em torno dos superiores objetivos da nação, seguindo o líder (duce), que é intérprete e guardião destes objetivos. A empresa, no ideário, fascista, representa justamente a organização em que se harmonizam as classes em conflito. Vale notar que Asquini, um dos expoentes da doutrina comercialista italiana, ao tempo do governo fascista, costumava apontar como um dos perfis da empresa o

127 COELHO, Fábio Ulhoa. Curso de Direito Comercial. Volume 1. São Paulo: Saraiva, 2008. p. 8.

128 MALUF, Sahid. Teoria Geral do Estado. 25 ed. atual. / pelo Prof. Miguel Alfredo Malufe Neto. São Paulo: Saraiva, 1999. p. 142. 
corporativo, em que se expressava a comunhão dos propósitos de empresários e trabalhadores. ${ }^{129}$

Huberman, cuja primeira edição de sua obra data de 1936, descreve o ambiente político-econômico italiano sob o regime fascista:

Da Itália nos vem uma história semelhante. Eis um dos pronunciamentos de Mussolini sobre as glórias do fascismo, igual a outros anteriores: "Nessa economia, os trabalhadores serão colaboradores do capital, com direitos e deveres iguais". Essas as palavras. Qual a realidade? John Gunther, em Inside Europe, nos escreve:

"Realmente, poderíamos reunir uma lista, aparentemente impressionante, de forças anticapitalistas no Estado corporativo. Nenhum empregador pode dispensar trabalhadores sem consentimento do governo. Nenhum capitalista pode realizar uma atividade independente relativamente pequena, como por exemplo aumentar sua fábrica, sem aprovação estatal. Os salários são determinados pelo governo $O$ dono de uma fábrica não pode liquidar seu negócio sem permissão do Estado; o governo controla as fontes do crédito, $e$ sujeita grande parte das rendas a um imposto draconiano.

Por outro lado, as desvantagens do trabalho no fascismo são infinitamente mais severas. Os trabalhadores perderam o direito de exigir. Seus sindicatos foram dissolvidos, seus salários podem ser (e foram) impiedosamente reduzidos por decretos; acima de tudo, perderam o direito de greve. O capitalista, por outro lado, mesmo que tenha sofrido restrições, mantém seu privilégio fundamental, o de ganhar lucros particulares. $O$ fascismo, tal como o introduziu Mussolini, não era,

129 HUBERMAN, Leo. História da Riqueza do Homem. 16 ed.. Disponível em: < http://www.controversia.com.br/antigo/uploaded/pdf/16574_huberman-historia-dariqueza-do-homem.pdf. >. Acessado em 20.09.2015. Tradução por Waltensir Dutra. p. 320-321. 
provavelmente, um artificio deliberado para proteger a estrutura capitalista (...)"

Mussolini propala frases sobre "direitos e deveres iguais", mas Gunther traça dos acontecimentos reais um quadro bem diferente. ${ }^{130}$

Este sistema permitia um rígido controle partidário, à medida que as corporações funcionavam como órgãos do Partido Fascista e que ninguém poderia exercer uma atividade qualquer sem prévia autorização corporativa.

Em face dos conflitos entre o capital e o trabalho, conseguiu o Estado fascista, inegavelmente, estabelecer uma paz duradoura, lançando mão dos contratos coletivos de trabalho e de uma completa organização corporativa das categorias profissionais. Manteve a iniciativa privada e a livre concorrência, subordinadas, porém, aos superiores interesses sociais. O trabalho foi considerado como dever social. O direito de greve foi abolido, e considerado qualquer movimento paredista como crime contra a organização corporativa estatal (...) A Carta do Trabalho, organizada pelo Grande Conselho do Fascismo, é o documento fundamental do regime corporativo italiano (...) Desbravou esse documento básico do fascismo largos caminhos, pelos quais a humanidade procurou e vem procurando encontrar a solução dos seus problemas, tanto assim que serviu de modelo a muitos códigos trabalhistas de outros países. (...) o regime político fascista foi funesto como todas as ditaduras. (...) arrastando o povo heroico da Itália a uma autêntica catástrofe nacional. ${ }^{131}$

\subsection{A evolução histórica do Direito Comercial no Brasil}

\footnotetext{
130 COELHO, Fábio Ulhoa. Manual de Direito Comercial: Direito de Empresa. São Paulo: Saraiva, 2010. p. 8.

131 MALUF, Sahid. Teoria Geral do Estado. 25 ed. atual. / pelo Prof. Miguel Alfredo Malufe Neto. São Paulo: Saraiva, 1999. p. 143-144.
} 
No período do Brasil Colonial, "as relações jurídicas pautavamse, como não podia deixar de ser, pela legislação de Portugal. Imperavam, portanto, as Ordenações Filipinas, sob a influência do direito canônico e do direito romano"132, o que restringia a atividade mercantil na colônia.

Quando, porém, a Família Real Portuguesa (que depois viria a se tornar a Família Imperial Brasileira), "acossada pelas tropas napoleônicas, refugiou-se na colônia, esta necessariamente haveria de evoluir em seu status" 133 . Foi nesse período que a atividade comercial começou a se estruturar. A abertura dos portos às nações amigas (1810) e a criação do Banco do Brasil (12.10.1808) são fatos que comprovam essa estruturação mercantil.

Em 1823, mesmo depois da independência, criou-se, no Brasil, uma lei que dizia que, para os Atos de Comércio, deveriam ser aplicadas as leis portuguesas, já que o país ainda não contava com um arcabouço jurídico próprio (Conjunto de Códigos e legislações).

Ou seja,

conquistada a sua independência, o Brasil viu-se na necessidade de criação de normas próprias para regular a atividade comercial, não obstante ainda se valesse da Lei da Boa Razão de 1769, legislação que, embora proveniente de Portugal, era invocada para dirimir as contendas em matéria comercial. ${ }^{134}$

A "Lei da Boa Razão", editada por Portugal, permitia que, na falta de previsão legal no Ordenamento jurídico pátrio, para um caso concreto, poder-se-ia aplicar, subsidiariamente, as leis de outros países, desde que também Cristãos.

Em função disso, o Código Comercial Francês era sempre a saída encontrada, pelo Brasil, para solucionar suas "pendengas". A aplicação das leis francesas em diversas situações permitiu, por causa desse contato, que os brasileiros aderissem à Teoria dos Atos de Comércio e a quisessem para o seu próprio Código, que viria mais tarde.

\footnotetext{
132 REQUIÃO, Rubens. Curso de Direito Comercial. São Paulo: Saraiva, 2007. p. 15.

133 Ibidem.
}

134 FERNANDES, Jean Carlos. Direito Empresarial Aplicado. Belo Horizonte: Del Rey, 2007. p. 5 
Destarte, "seguindo essa tendência, editou-se no Brasil, em 1850, a Lei 556, criando o Código Comercial Brasileiro ${ }^{135}$ e, assim, adotando a Teoria dos Atos de Comércio, nos moldes do Código Comercial francês". ${ }^{136}$

Tendo entrado em vigor em $1^{\circ}$ de janeiro de 1851 , sob o título de Código Comercial do Império do Brasil, continha 1.003 artigos; divididos em três partes, tratando a primeira "do comércio em geral", com 18 títulos e 455 artigos; a segunda "do comércio marítimo", com 13 títulos e 341 artigos; a terceira "das quebras", com 8 títulos e 177 artigos, completado por um Título Único, com 30 artigos sobre a "administração da Justiça nos negócios e nas causas comerciais", dividindo em dois capítulos: um sobre tribunais e Juízos do Comércio e o outro sobre a ordem do Juízo nas causas comerciais. ${ }^{137}$

Com a adoção da teoria da empresa pelo código civil italiano de 1942, unificador legislativo do direito privado naquele país, os juízos e tribunais pátrios começaram, aos poucos, sobretudo a partir da década de 1960, a aplicarem aquela doutrina em muitas relações comerciais submetidas ao judiciário brasileiro.

Durante um quarto de século, enquanto pouca coisa ou nada acontecia no Congresso e a doutrina comercialista já desenvolvia suas reflexões à luz da teoria da empresa, alguns juízes começaram a decidir processos desconsiderando o conceito de atos de comércio, embora fosse este ainda o do direito positivo, porque ainda em vigor o antigo Código Comercial. Estes juízes concederam a pecuaristas

\footnotetext{
135 Insta constar a participação do insigne Barão e Visconde com Grandeza de Mauá, Irineu Evangelista de Souza, na elaboração do projeto de lei que veio a se tornar o Código Comercial do Império do Brasil (Lei 556), de 1850, e de seu Regulamento (Decreto 737), também de 1850.

136 MAMEDE, Gladston. Direito Empresarial brasileiro: empresa e atuação empresarial, volume 1. 7. ed. São Paulo: Atlas, 2013. p. 18.

137 BULGaRELli, Waldirio. Direito Comercial. 13. ed. ed. São Paulo: Atlas, 1998. p. 40 .
} 
um favor legal então existente apenas para os comerciantes (a concordata), decretaram a falência de negociantes de imóveis, asseguraram a renovação compulsória do contrato de aluguel em favor de prestadores de serviço, julgando, enfim, as demandas pelo critério da empresarialidade. Durante este largo tempo, também, as principais leis de interesse do direito comercial editadas já se inspiraram no sistema italiano, e não mais no francês. São exemplos o Código de Defesa do Consumidor de 1990, a Lei de Locação Predial Urbana de 1991 e a Lei do Registro de Empresas de 1994. ${ }^{138}$

Insta constar que, antes dessa prática jurisprudencial, porém, o ditador Getúlio Vargas, líder-governante de cunho fascista do "Estado Novo" brasileiro, decretou a aprovação da Consolidação das Leis do Trabalho, por meio do Decreto-Lei $\mathrm{n}^{\circ} 5.452$, de $1^{\circ}$ de maio de 1943, que unificou toda a legislação trabalhista até então existente no Brasil. Esse estatuto laboral foi forte e diretamente influenciado pela Carta del Lavoro italiana (1927), da lavra do governo fascista de Benito Mussolini.

Depois de algumas tentativas de unificação do Direito Privado em um mesmo Diploma legal, de cujo exemplo é o projeto de código das obrigações de 1965 (não convertido em lei),

o Projeto de Código Civil, que tramitava no Congresso Nacional desde 1975, cujo anteprojeto foi elaborado por uma comissão de juristas coordenada pelo Prof. Miguel Reale, finalmente recebeu a sanção presidencial em 10 de janeiro de 2002, dando origem à Lei 10.406, de 10.01.2002 - Código Civil. ${ }^{139}$

Acontece que o principal artífice da comissão de juristas para elaboração de um novo código civil brasileiro, o inolvidável Miguel Reale, ele próprio filho de um médico italiano (Brás Reale) e de família ma-

138 COELHO, Fábio Ulhoa. Manual de Direito Comercial: Direito de Empresa. São Paulo: Saraiva, 2010. p. 9.

139 BERTOLDI, Marcelo M.; RIBEIRO, Marcia Carla Pereira. Curso Avançado de Direito Comercial. São Paulo: Revista dos Tribunais, 2006. p. 29. 
terna também de ascendência italiana, foi militante em sua juventude da Ação Integralista Brasileira (AIB), partido de inspiração fascista brasileiro, dissolvido com o golpe de Estado engendrado por Getúlio Vargas em 1937, que instituiu o Estado Novo. Trata-se, portanto, de um código civil altamente influenciado pelo fascismo, inclusive adotando a Teoria da Empresa e efetuando a unificação legislativa dos dois ramos do direito privado.

Não poderia o novo estatuto do direito privado, assim, deixar de escapar, como não escapou, de severas críticas por parte da doutrina. Eis as considerações feitas por Tepedino ${ }^{140}$, para quem o Código de 2002

peca, a rigor, duplamente: do ponto de vista técnico, desconhece as profundas alterações trazidas pela Carta de 1988, pela robusta legislação especial e, sobretudo, pela rica jurisprudência consolidada na experiência constitucional da última década. Demais disso, procurando ser neutro e abstrato em sua dimensão axiológica, como ditava a cartilha das codificações dos Séculos XVIII e XIX, reinstitui, purificada, a técnica regulamentar.

E, do mesmo modo, Azevedo ${ }^{141}$, ao analisar o caráter tímido do diploma civil, já salientava, antes mesmo de sua publicação, que o "Projeto serve-se também largamente de noções vagas (por exemplo, função social dos contratos) e pretende a todo custo manter a concepção de unidade do direito privado".

2

DIREITO COMERCIAL OU DIREITO EMPRESARIAL? A
ADEQUABILIDADE DOS TERMOS NOS
PENSAMENTOS DOS JUS-EMPRESARIALISTAS E
NAS GRADES CURRICULARES DOS CURSOS DE
DIREITO NO BRASIL

140 TEPEDINO, Gustavo. O Código Civil, os microssistemas e Constituição: premissas para uma reforma legislativa. Acesso em: 30 mar. 2010.

141 AZEVEDO, Antonio Junqueira de. O Direito Pós-Moderno e a Codificação. In: Revista de Direito do Consumidor. Vol. 33. Jan/2000. São Paulo: Revista dos Tribunais. Acesso em: 07 jun. 2012, p. 05. 
Objetivando uma análise ao mesmo tempo qualitativa e quantitativa, optou-se em embasá-la, de um lado, na Opinião dos JusEmpresarialistas, e, de outro, no resultado da tabulação de dados dos designativos presentes nas Grades Curriculares dos Cursos de Direito brasileiros portadores do Selo "OAB Recomenda" (Edição 2012).

\subsection{Communis opinio doctorum: o designativo mais adequado nos pensamentos dos jus-empresarialistas}

A doutrina é fonte do direito, vez que se constitui meio verdadeiramente propício à formação do melhor critério de interpretação, na medida em que oferece um fundo científico e consistente às normas jurídicas.

O douto Mendonça a elenca expressamente como fonte formal do Direito, afirmando que:

Os analistas acrescentam, com frequência, a doutrina como mais uma fonte do Direito Positivo. Pensa-se em doutrina como o costumeiro pensamento dos doutos. Assim, ela não passa, também, de uma reiteração, agora, da forma de pensar o fenômeno jurídico pelos doutos (...) ela tem sempre como objeto ou o fato social (do qual emerge o costume) ou as decisões judiciárias (que já analisamos sob o rótulo de jurisprudência) ou as leis. ${ }^{142}$

Partindo desse pressuposto (e tendo ciência da subjetividade dos escritos doutrinários), é que se optou neste trabalho em dar nota das opiniões dos Doutrinadores de Direito Comercial/Empresarial. Importante reflexão sobre a Doutrina, seu conceito e sua utilidade, é feita por Villey, para quem:

142 MENDONÇA, Jacy de Souza. Introdução ao Estudo do Direito. São Paulo: Rideel, 2010. p. 76. 
Uma doutrina, etimologicamente, é um ensinamento. Ora, um ensinamento é sempre pessoal. É a mensagem de um homem a outros homens. No seu ensinamento, um mestre exprime não somente ideias, ele se exprime a si mesmo. A doutrina é, então, um pensamento que não se objetivou totalmente, caído no domínio público, mas que permanece ligado àquele que a concebeu. ${ }^{143}$

Tem-se, assim, com Corrêa ${ }^{144}$, que doutrina "seria a tese sustentada pelo autor, dentro de certos princípios que prega e que admitem a controvérsia", em matéria não definitivamente estabelecida pela ciência jurídica: significaria, portanto, "a concepção pessoal do expositor, batida de personalismo, a que se não pode fugir”.

Braz $^{145}$, no entanto, termina por sentenciar a importância da doutrina jurídica para a formação do Direito contemporâneo: "não se pode utilizar decisões judiciais isoladas como fonte orientadora da doutrina jurídica, a contrario sensu, é a orientação doutrinária que deve alimentar o conteúdo das decisões judiciais".

O Compêndio histórico do Comércio e do Direito Comercial não se encontra no presente trabalho por acaso. Alguns autores utilizamse dessa interpretação histórica e de algumas Teorias, surgidas ao longo da história, para justificar a escolha por algum designativo específico.

Com efeito, nas primeiras fases da Evolução do Ius Mercatorum, desde o surgimento do Comércio, passando pela fase das Corporações de Ofício, até o Código Napoleônico, com seus Atos de Comércio (ou seja, da Teoria subjetivista à dos Atos de Comércio), era tendente a nomenclatura primeiro de Direito Mercantil e, depois, de Direito Comercial. Todavia, com o alvorecer da Teoria da Empresa, nos idos do século XX, o designativo Direito Empresarial desponta como melhor terminologia, no entender de alguns.

No Brasil, com o novo Código Civil, a Empresa (e o Empresário) assume $(\mathrm{m})$ um papel de destaque nas relações econômico-sociais

143 CORRÊA, Oscar Dias. Ciência, Teoria e Doutrina Econômica. Revista da Faculdade de Direito da UFMG. v. 4, 1952, p. 67.

144 Idem. p. 64.

145 BRAZ, Petrônio. Tratado de Direito Municipal - Volume III: Sistema Tributário Municipal e Responsabilidade Fiscal. 2a edição. Leme/SP: Mundo Jurídico, 2007. p. 200. 
brasileiras, principalmente no terceiro milênio. Ou seja, "nos dias que correm, transmudou-se [o direito comercial] de mero regulador dos comerciantes e dos atos de comércio, passando a atender à atividade, sob forma de empresa, que é o atual fulcro do Direito Comercial". ${ }^{146}$

Nesse mesmo sentido, Reale ${ }^{147}$ destaca que:

Uma das inovações da nova lei civil de 2002 consta na disciplina autônoma da vida societária, destinando-lhe uma das partes especiais, à qual foi dada o nome de Direito de Empresa. Essa denominação se justifica porque nela se trata mais amplamente da 'sociedade empresária', que pode ser comercial, industrial ou de prestação de serviços, sendo organizadas segundo um dos tipos previstos no Código.

Ramos $^{148}$ se pergunta sobre qual é o termo mais adequado para se utilizar atualmente, quando escreve o "E agora: Direito Comercial ou Direito Empresarial?". Para ele,

Não se pode negar que o uso da expressão direito comercial se consagrou no meio jurídico acadêmico e profissional, sobretudo porque foi o comércio, desde a Antiguidade, como dito, a atividade precursora deste ramo do direito. Ocorre que, como bem destaca a doutrina comercialista, há hoje outras atividades negociais, além do comércio, como a indústria, os bancos, a prestação de serviços, entre outras. ${ }^{149}$

Ele acredita, portanto, que, na hodiernidade,

\footnotetext{
146 BULGARELli, Waldirio. Direito Comercial. 13. ed. ed. São Paulo: Atlas, 1998. p. 19.

147 REALE, Miguel. Lições preliminares de Direito. 27. ed. São Paulo: Saraiva, 2004. p. 243.

148 RAMOS, André Luiz Santa Cruz. Direito Comercial ou Direito Empresarial?: Notas sobre a Evolução Histórica do Ius Mercatorum. In: Revista Síntese de Direito Civil e Processual Civil, v. 7, 2006.

149 Idem. p. 44-45.
} 
o direito comercial não cuida apenas do comércio, mas de toda e qualquer atividade econômica exercida com profissionalismo, intuito lucrativo e finalidade de produzir ou fazer circular bens ou serviços. Dito de outra forma: o direito comercial, hoje, cuida das relações empresariais, e por isso alguns têm sustentado que, diante dessa nova realidade, melhor seria usar a expressão direito empresarial. ${ }^{150}$

Não obstante entenda que seria interessante a uniformidade na referência a este importante ramo da árvore jurídica, $\operatorname{Ramos}^{151}$ entende que o Direito Comercial, por ser uma terminologia tradicional, ainda é por muitos utilizada e que não há maiores problemas por causa disso. No entanto, ele afirma que devido à adoção, pelo ordenamento jurídico brasileiro, da Teoria da Empresa, a nomenclatura mais adequada é a de Direito Empresarial.

Para Souza, também adepta a utilização do termo Direito Empresarial,

com a promulgação do Código Civil de 2002, foi inserido no ordenamento jurídico brasileiro o Direito Empresarial revogando o Direito Comercial, juntamente com a primeira parte do Código Comercial ${ }^{152}$. Este era regulado pela teoria dos atos de comércio, dependendo de descrição legal dos mesmos para determinar quais atividades eram tuteladas. Por sua vez, o Direito Empresarial está fundamentado na teoria da atividade da empresa,

150 RAMOS, André Luiz Santa Cruz. Direito Comercial ou Direito Empresarial?: Notas sobre a Evolução Histórica do Ius Mercatorum. In: Revista Síntese de Direito Civil e Processual Civil, v. 7, 2006. p. 45.

${ }^{151}$ RAMOS, André Luiz Santa Cruz. Curso de Direito Empresarial: o novo regime jurídico-empresarial brasileiro. Salvador: JusPodivm, 2009.

${ }_{152}$ É importante esclarecer que, de acordo com Hentz (apud NEGRÃO, 2013, p. 34), o Direito Comercial não desaparece com o novo Código, mas renasce como Direito de Empresa. 
sendo esta a atividade economicamente organizada com o fim de lucro. ${ }^{153}$

Outro autor que compartilha dos pensamentos de Ramos ${ }^{154} \mathrm{e}$ Souza ${ }^{155}$ é Cometti ${ }^{156}$. Os três são uníssonos em advogar pela utilização do designativo Direito Empresarial, partindo do argumento da "Teoria da Empresa".

Assim, para Cometti,

o ponto de partida para a identificação da diferença entre empresário e comerciante, empresa e comércio, estabelecimento empresarial e comercial está na teoria adotada pelo nosso ordenamento jurídico para a identificação do sujeito de certas normas específicas do Direito Privado, como a Lei de Falência e Recuperação de Empresas. ${ }^{157}$

Isto é, para o supracitado Jus-Empresarialista,

sob a vigência da Teoria da Empresa, portanto, nada mais correto do que designar o seu sujeito como empresário; a atividade por ele explorada como empresa; o conjunto de bens por ele organizado para exploração de sua atividade como estabelecimento empresarial; e o ramo do Direito Privado composto

153 SOUZA, Nadialice Francischini de. Direito Empresarial: muito além do Direito Comercial. Disponível em: < http://revistadireito.com/direito-empresarial-muito-alem-dodireito-comercial/ > . Acessado em 21 de Abril de 2014.

154 RAMOS, André Luiz Santa Cruz. Curso de Direito Empresarial: o novo regime jurídico-empresarial brasileiro. Salvador: JusPodivm, 2009.

155 SOUZA, Nadialice Francischini de. Direito Empresarial: muito além do Direito Comercial. Disponível em: < http://revistadireito.com/direito-empresarial-muito-alem-dodireito-comercial/ > . Acessado em 21 de Abril de 2014.

156 COMETTI, Marcelo Tadeu. Empresário e Comerciante - Direito Empresarial e Direito Comercial: apenas uma diferença terminológica? Disponível em: < http://www.migalhas.com.br >. Acessado em 21 de Abril de 2014.

157 Ibidem. 
por normas a ele destinadas como Direito Empresarial. ${ }^{158}$

Para Führer ${ }^{159}$, a fase que se encontra o Direito Comercial atualmente "corresponde ao Direito Empresarial (conceito subjetivo moderno)". Ou seja, "com o advento do novo Código Civil, de 2002, o comércio passou a representar apenas uma das várias atividades reguladas por um Direito mais amplo, o Direito Empresarial" "160. E com ele corrobora Fernandes, que advoga ser o Ius Mercatorum "hodiernamente designado como Direito Empresarial ou Direito da Empresa, em razão da adoção da teoria da empresa pelo Código Civil de 2002, inspirado no Código Civil italiano de 1942" "'

Entre outros nomes do Direito Comercial/Empresarial brasileiro que defendem a nomenclatura Direito Empresarial está o de Cavalli ${ }^{162}$, para quem o Direito Comercial é entendido atualmente como Direito de Empresa; e o de Reis ${ }^{163}$, que optou por essa terminologia ao dar o nome a seu livro "Manual de Direito Empresarial".

Negrão comenta que, hoje,

busca-se [...] uma nova conceituação para o Direito Comercial, como sendo o Direito de Empresa. A terminologia foi adotada pelo Codice Civile de 1942, na Itália, e integra [como já esclareceu Reale] o livro

158 COMETTI, Marcelo Tadeu. Empresário e Comerciante - Direito Empresarial e Direito Comercial: apenas uma diferença terminológica? Disponível em: < http://www.migalhas.com.br >. Acessado em 21 de Abril de 2014.

159 FÜHRER, Maximilianus Cláudio Américo. Resumo de Direito Comercial. São Paulo: Malheiros Editores, 2004. p. 14.

${ }^{160}$ Idem. p. 15.

161 FERNANDES, Jean Carlos. Direito Empresarial Aplicado. Belo Horizonte: Del Rey, 2007. p, 69.

162 CAVAlli, Cássio Machado. A Evolução Histórica do Direito Comercial: do Particularismo Medieval ao Microssistema Constitucionalizado. Dissertação de Mestrado, Porto Alegre, PUC-RS, 2006.

163 REIS, Jair Teixeira dos. Manual de Direito Empresarial: noções gerais de Direito. São Paulo: RCS Editora, 2006. p, 324. 
II da Parte Especial do Novo Código Civil brasileiro (Do Direito de Empresa). ${ }^{164}$

A dificuldade que se tinha para se encontrar um conceito legal de Empresa acabava por problematizar a situação do novo rótulo para o ramo jurídico em tela. $\mathrm{O}$ que encorajou Negrão, por parecer mais adequado a priori, a chamá-lo de Direito Comercial e, em seguida, conceituá-lo como "o ramo privado que regula a atividade do antigo comerciante e do moderno empresário, bem como suas relações jurídicas, firmadas durante o exercício profissional das atividades mercantis e empresárias". ${ }^{165}$

Todavia, ao final do capítulo primeiro de seu "Manual de Direito Comercial e de Empresa" 166 , Negrão, estribado nas ideias de Hentz, diz o seguinte:

É preferível, pois, utilizar, como terminologia decorrente da unificação, a expressão 'Direito de Empresa', englobando os aspectos históricos e doutrinários do Direito Comercial - como direito dos comerciantes e direito dos atos de comércio - e os novos institutos do empresário, da sociedade empresária, do estabelecimento etc. ${ }^{167}$

Em contrapartida, pode-se elencar, outrossim, grandes nomes de juristas que defendem a utilização do designativo Direito Comercial. De maneira tolerante e com lentes positivistas, Sharp Júnior comenta sobre o assunto:

E é de se notar que a CF/1988 menciona Direito Comercial, e não empresarial, da empresa ou dos negócios. Por esse motivo é que se deve privilegiar a

${ }^{164}$ NEGRÃO, Ricardo. Manual de Direito Comercial e de Empresa. 10. ed. São Paulo: Saraiva, 2013. p. 33.

${ }^{165}$ Idem. p. 34.

166 O título da Obra de Ricardo Negrão é demonstrativo da dúvida, da incerteza do autor em relação à nomenclatura da disciplina jurídica em pauta. Para não ser questionado, talvez, ele optou por utilizar, em seu Manual, os termos "Direito Comercial" e, outrossim, "Direito de Empresa", simultaneamente.

${ }^{167}$ NEGRÃO, Ricardo. Manual de Direito Comercial e de Empresa. 10. ed. São Paulo: Saraiva, 2013. p. 34. 
nomenclatura Direito Comercial em detrimento de outras. Mas não estranhe se eventualmente o programa do edital ou as questões da prova aludirem à 'Direito Empresarial'. No fundo, serão a mesma coisa. ${ }^{168}$

Insta constar que tramitam no Congresso Nacional, no presente momento, dois projetos de lei que visam a instituir um novo código comercial no Brasil. Tratam-se do Projeto de Lei n. ${ }^{\circ}$ 1572/2011, que conta com 670 artigos, disciplinando as mais variadas matérias; e o Projeto de Lei n. ${ }^{\circ} 487 / 2013$, que é ainda mais amplo: com 1.102 artigos, este projeto, "a pretexto de regular o direito comercial, acaba interferindo em diversas outras áreas do Direito, nem sempre primando pela boa técnica". ${ }^{169}$

Mesmo tacitamente, Coelho parece ter uma preferência pelo designativo Direito Comercial, principalmente a julgar pelo título de seus livros: "Curso de Direito Comercial" e "Manual de Direito Comercial". No entanto, ao comentar sobre a autonomia do Direito Comercial, ele aceita outras terminologias como, por exemplo, Direito Mercantil, Direito Empresarial (que inclusive está presentes nos subtítulos de suas obras) e Direito dos Negócios. ${ }^{170}$

A predileção de Coelho é confirmada quando o mesmo busca conceituar o ramo do Direito em pauta. São palavras do autor:

Direito Comercial é a designação tradicional do ramo jurídico que tem por objeto os meios socialmente estruturados de superação dos conflitos de interesse entre os exercentes de atividades de

\footnotetext{
168 SHARP JÚNIOR, Ronald Amaral. Direito Comercial e de Empresa. Rio de Janeiro: Elsevier, 2009. p. 3.

169 MÜSSNICH, Francisco Antunes Maciel. A quem interessa um novo código comercial?. Revista RI, fevereiro de 2014, p. 42-46. Disponível em: < http://www.abrasca.org.br/Uploads/autoregulacao/RI180_Forum_Abrasca_a_quem_Intere ssa_Novo_Codigo_Comercial.pdf >. Acessado em 29.12.2014. p. 43.

${ }^{170}$ COELHO, Fábio Ulhoa. Manual de Direito Comercial: Direito de Empresa. São Paulo: Saraiva, 2010. p, 25.
} 
produção ou circulação de bens ou serviços de que necessitamos todos para viver. ${ }^{171}$

O silêncio de Fazzio Júnior levanta a possibilidade de interpretação de que o mesmo prefere o termo Direito Comercial, pois o título de sua obra (Manual de Direito Comercial), aliado à utilização frequente do designativo na primeira parte do livro, sugere a preferência do autor pelo termo mais tradicional. ${ }^{172}$

O título da obra de Requião também é indicativo da preferência do autor pelo designativo mais tradicional, já que foi intitulada de "Curso de Direito Comercial". ${ }^{173}$

Sobre esse debate, comenta Castro Júnior 174: "Eu chamo de Direito Comercial, até porque Direito Empresarial é uma especialização que engloba os Direitos Comercial, Trabalhista e Tributário". A interpretação adequada às palavras de Castro Júnior é a de que, para ele, o Direito Empresarial é gênero, do qual o Comercial seria espécie. Nesse sentido, além do Direito Comercial, o Empresarial dialogaria, ainda, com o Direito Tributário e com o Direito Trabalhista.

Análise parecida faz Bottallo ${ }^{175}$ et al), quando este organiza um livro de Direito Empresarial dividindo-o em três volumes: I) o primeiro intitulado de Direito Comercial; II) o segundo, Direito Tributário; III) e, por último, Direito Econômico ${ }^{176}$. Ou seja, para ele, o Direito Empresarial seria, assim como para Castro Júnior ${ }^{177}$, um gênero que dialogaria com

\footnotetext{
${ }^{171}$ COELHO, Fábio Ulhoa. Curso de Direito Comercial. Volume 1. São Paulo: Saraiva, 2008. p. 27.

172 FAZZIO JÚNIOR, Waldo. Manual de Direito Comercial. 8. ed. São Paulo: Atlas, 2007. p, 420.

${ }^{173}$ REQUIÃO, Rubens. Curso de Direito Comercial. São Paulo: Saraiva, 2007. p, 98.

174 CASTRO JÚNIOR, Armindo. Direito Comercial ou Direito Empresarial?: breves colocações acerca dessa hodierna discussão. Cuiabá (MT): Universidade de Cuiabá, 2014. (Palestra). p, 308.

175 BOTTAllo, Eduardo Domingos (Org.). Curso de Direito Empresarial: Direito Tributário. Volume II. São Paulo: Editora Resenha Tributária; Editora da Universidade Católica, 1976.

176 As referências desses livros encontram-se na parte final deste artigo, como pode se ver.

177 CASTRO JÚNIOR, Armindo. Direito Comercial ou Direito Empresarial?: breves colocações acerca dessa hodierna discussão. Cuiabá (MT): Universidade de Cuiabá, 2014. (Palestra).
} 
outros ramos jurídicos. Só que em vez de Direito do Trabalho, Botallo opta por Direito Econômico para completar a tríade.

Com convicção e personalidade, Barbosa traça análise das características, conceitos, princípios e diferenças entre estes diferentes ramos do Direito Privado. Para ele,

O Direito Empresarial, ramo do direito que ainda não foi devidamente estudado pela doutrina nacional, trata da empresa e suas relações jurídiconegociais. Nele pode-se incluir: o Direito Comercial, o Direito Econômico, o Direito do Consumidor, a Teoria Geral dos Contratos e os Contratos Comerciais, Financeiros e Bancários; o Direito das Marcas, Patentes e Propriedades Industriais e Comerciais, somente para citar alguns. ${ }^{178}$

A ideia central, a partir da qual Barbosa faz a defesa dessa nova área do Direito, "repousa na necessidade de se especializar a prestação e a assessoria jurídica às empresas e empreendedores nacionais". Aponta, assim, para a importância, facilmente verificável, de se analisar e conhecer, de maneira sistêmica, "todos os ramos do direito que influenciam diretamente a atividade empresarial nacional", assinalando para a patente relação umbilical, "a complementaridade e, por que não falar, a interseção entre os ramos citados acima”. E apregoa:

Como discutir o Direito Econômico, essencialmente um direito garantidor do equilíbrio das forças de mercado e do consumidor, sem entrar nos conceitos e definições do Direito Comercial?

Como discutir as relações de consumo, cliente e fornecedor, sem transitar com maestria entre os conceitos de empresa, empresário, marcas e patentes?

De que forma um professor poderia motivar seus alunos a conhecerem os Contratos Comerciais,

178 BARBOSA, Washington. Direito Empresarial Versus Direito Comercial. Disponível em: < http://www.juristas.com.br/informacao/artigos/direito-empresarialversus-direito-comercial/154/ >. Acessado em 29.12.2014. 
Financeiros e Bancários sem adentrar nas características dos empreendimentos mercantis, das relações de consumo e dos Princípios Econômicos Constitucionais? ${ }^{179}$

Para, deste modo, concluir:

O que se vê claramente é o surgimento de um novo ramo do Direito, o Direito Empresarial, que ainda não mereceu o devido destaque na Doutrina Nacional e que vem encontrando resistência de alguns que insistem em reduzi-lo a sinônimo do Direito Comercial. Alguns, pela intenção consciente de não lhe permitir o nascimento; outros por conta de conclusões precipitadas, fruto de uma análise superficial e apressada do tema. ${ }^{180}$

Fecha, ademais, com um apelo para que "os doutrinadores, os estudiosos e os operadores do direito se debrucem sobre o assunto e enriqueçam a discussão" (o que é o nosso intento), e que "não se permita que interesses pessoais e/ou editorais possam frustrar os possíveis investimentos para o reconhecimento da autonomia do Direito Empresarial de maneira definitiva". Valendo lembrar que "o Direito não é o passado que condiciona o presente, mas o presente que constrói o futuro". ${ }^{181}$

Já Mamede é outro que, apesar de utilizar o designativo Direito Empresarial nos títulos de suas obras, entende que é possível a utilização de outros rótulos para esse ramo jurídico. Segundo ele:

O rótulo [...] é de somenos importância: Direito de Empresa, Direito Empresarial ou, respeitadas as influências históricas, Direito Mercantil ou Direito do Comércio ou Direito Comercial; em todos os casos, tem-se a mesma coisa, distinguindo-se apenas

179 BARBOSA, Washington. Direito Empresarial Versus Direito Comercial. Disponível em: < http://www.juristas.com.br/informacao/artigos/direito-empresarialversus-direito-comercial/154/ >. Acessado em 29.12.2014.

${ }^{180}$ Ibidem.

${ }^{181}$ COELHO, Fábio Ulhoa. Curso de Direito Comercial. Volume 1. São Paulo: Saraiva, 2008. p. 476. 
os ângulos a partir do qual concebe o rótulo: o sujeito (a empresa), a atividade (o comércio, em sentido amplo, vencidas as limitações do Regulamento 737/1850) ou o ambiente (o mercado). ${ }^{182}$

Apesar de "liberal" nesse quesito, Mamede ${ }^{183}$, exatamente por ser um defensor da fusão entre Atividades Empresariais e Atividades Simples, tem a sua preferência: o designativo Direito Negocial (ou Direito da Atividade Negocial), termo inclusive já adotado pelo "Mestrado em Direito Negocial", da Universidade Estadual de Londrina (PR).

Veloso ${ }^{184}$ é outro que com o seu silêncio, somado à escolha do título da sua Obra (Essência do Direito Comercial), torna possível a conclusão de que o mesmo prefere o designativo mais tradicional, qual seja, o de Direito Comercial.

Em resumo, pode-se perceber, pelas opiniões acima explanadas, uma variedade de possibilidades, seja pela escolha do designativo, seja pela justificativa da escolha. Isso acontece, pois:

Se buscarmos na linguagem dos doutores os termos precisos para as ideias, a fim de se estabelecerem as diferenças, usando-se para cada ideia a palavra exata, vamos encontrar as maiores dificuldades. Os autores (nem podia deixar de ser) carregam as palavras de valoração pessoal e aos mesmos vocábulos dão, às vezes, significação diversa da real e aceita. Esse o grande drama das discussões científicas e, especialmente, das ciências sociais. ${ }^{185}$

\footnotetext{
${ }^{182}$ MAMEDE, Gladston. Direito Empresarial brasileiro: empresa e atuação empresarial, volume 1. 7. ed. São Paulo: Atlas, 2013. p. 24.

183 Ibidem.

184 VELOSO, Waldir de Pinho. Essência do direito comercial. Montes Claros: Unimontes, 2001.

185 CORRÊA, Oscar Dias. Ciência, Teoria e Doutrina Econômica. Revista da Faculdade de Direito da UFMG. v. 4, 1952, p. 63.
} 


\subsection{As grades curriculares dos cursos de Direito e a utilização dos designativos "Direito Comercial" e "Direito Empresarial" como nomes de disciplinas}

No que tange à escolha do designativo mais adequado em relação ao Direito Privado em tela, os cursos jurídicos também se veem nessa encruzilhada, tendo eles, cada qual, de fazer sua opção. Destarte, empreendeu-se pesquisa quantitativa das Grades Curriculares dos Cursos de Direito, tendo por como recorte os detentores do Selo "OAB Recomenda" (Edição 2012).

O Programa "OAB Recomenda" foi muito pertinente nesta pesquisa, pois permitiu à autoria deste trabalho ter um recorte de Instituições e Cursos Jurídicos para se avaliar as suas matrizes curriculares e, por conseguinte, tabular dados que servirão como subsídio para melhor análise do mais adequado designativo: Direito Comercial ou Direito Empresarial.

Segue abaixo a "Tabela 1" com os dados, pela autoria colhidos, demonstrando, além do Nome da instituição (do Campus e da UF), a Nomenclatura da Disciplina utilizada.

\section{TABELA 1}

A Nomenclatura da Disciplina em pauta nos Cursos de Direito (ou Ciências Jurídicas) detentores do Selo "OAB Recomenda" (Edição 2012).

\begin{tabular}{|c|c|c|c|}
\hline Nome da Instituição & Campus & F & $\begin{array}{c}\text { Nomenclatura } \\
\text { da Disciplina }\end{array}$ \\
\hline Universidade Federal de Alagoas & $\begin{array}{c}\text { A. C } \\
\text { Simões }\end{array}$ & L & $\begin{array}{c}\text { Direito Empre- } \\
\text { sarial }\end{array}$ \\
\hline $\begin{array}{c}\text { Universidade do Estado do Ama- } \\
\text { zonas }\end{array}$ & Manaus & M & $\begin{array}{c}\text { Direito Empre- } \\
\text { sarial } \\
\text { Universidade Federal do Amapá }\end{array}$ \\
$\begin{array}{c}\text { Universidade Católica do Salva- } \\
\text { dor }\end{array}$ & Federação & AP & $\begin{array}{c}\text { Direito Comer- } \\
\text { cial }\end{array}$ \\
\hline $\begin{array}{c}\text { Universidade do Estado da Bahia } \\
\text { sarial }\end{array}$ \\
\hline
\end{tabular}




\begin{tabular}{|c|c|c|c|}
\hline & & A & sarial \\
\hline $\begin{array}{l}\text { Universidade Estadual de Feira } \\
\text { de Santana }\end{array}$ & Feira de Santana & A & $\begin{array}{l}\text { Direito Comer- } \\
\quad \text { cial }\end{array}$ \\
\hline $\begin{array}{c}\text { Universidade Estadual de Santa } \\
\text { Cruz }\end{array}$ & Ilhéus & A & $\begin{array}{l}\text { Direito Empre- } \\
\text { sarial }\end{array}$ \\
\hline $\begin{array}{l}\text { Universidade Estadual do Sudo- } \\
\text { este da Bahia }\end{array}$ & $\begin{array}{l}\text { Vitória da Con- } \\
\text { quista }\end{array}$ & A & $\begin{array}{l}\text { Direito Empre- } \\
\text { sarial }\end{array}$ \\
\hline Universidade Federal da Bahia & Canela & A & $\begin{array}{l}\text { Direito Empre- } \\
\text { sarial }\end{array}$ \\
\hline $\begin{array}{c}\text { Universidade Estadual do Vale do } \\
\text { Acaraú }\end{array}$ & Betânia & $\mathrm{E}$ & $\begin{array}{l}\text { Direito Comer- } \\
\text { cial }\end{array}$ \\
\hline Universidade Federal do Ceará & Benfica & $\mathrm{E}$ & $\begin{array}{l}\text { Direito da Em- } \\
\text { presa }\end{array}$ \\
\hline Universidade Regional do Cariri & São Miguel & $\mathrm{E}$ & $\begin{array}{l}\text { Direito Empre- } \\
\text { sarial }\end{array}$ \\
\hline Centro Universitário de Brasília & Brasília & $\mathrm{F}$ & $\begin{array}{l}\text { Direito Empre- } \\
\text { sarial }\end{array}$ \\
\hline Universidade de Brasília & Darcy Ribeiro & $\mathrm{F}$ & $\begin{array}{l}\text { Direito Comer- } \\
\quad \text { cial }\end{array}$ \\
\hline Faculdade de Direito de Vitória & Vitória & $\mathrm{S}$ & $\begin{array}{l}\text { Direito Empre- } \\
\quad \text { sarial }\end{array}$ \\
\hline $\begin{array}{c}\text { Universidade Federal do Espírito } \\
\text { Santo }\end{array}$ & Goiabeiras & $\mathrm{S}$ & $\begin{array}{l}\text { Direito de Em- } \\
\text { presa }\end{array}$ \\
\hline Universidade Federal de Goiás & $\begin{array}{c}\text { Unidade Sede/ } \\
\text { Campus avançado de } \\
\text { Goiás }\end{array}$ & $\mathrm{O}$ & $\begin{array}{l}\text { Direito Empre- } \\
\text { sarial }\end{array}$ \\
\hline $\begin{array}{l}\text { Unidade de Ensino Superior Dom } \\
\text { Bosco }\end{array}$ & Unidade Sede & A & $\begin{array}{l}\text { Direito Empre- } \\
\text { sarial }\end{array}$ \\
\hline $\begin{array}{l}\text { Universidade Federal do Mara- } \\
\text { nhão }\end{array}$ & $\begin{array}{l}\text { Campus do Bacan- } \\
\text { ga/ Campus Impera- } \\
\text { triz }\end{array}$ & A & $\begin{array}{l}\text { Direito Comer- } \\
\quad \text { cial }\end{array}$ \\
\hline $\begin{array}{c}\text { Centro Universitário Newton } \\
\text { Paiva }\end{array}$ & $\begin{array}{l}\text { Campus Carlos } \\
\text { Luz }\end{array}$ & $\mathrm{G}$ & $\begin{array}{l}\text { Direito Empre- } \\
\text { sarial }\end{array}$ \\
\hline $\begin{array}{l}\text { Faculdade de Direito Milton } \\
\text { Campos }\end{array}$ & Campus I & $\mathrm{G}$ & $\begin{array}{l}\text { Direito Empre- } \\
\quad \text { sarial }\end{array}$ \\
\hline $\begin{array}{c}\text { Faculdades Integradas Vianna Jú- } \\
\text { nior }\end{array}$ & Juiz de Fora & $\mathrm{G}$ & $\begin{array}{l}\text { Direito Empre- } \\
\quad \text { sarial }\end{array}$ \\
\hline Pontifícia Universidade Católica & São Gabriel/ Cora- & & Direito Empre- \\
\hline
\end{tabular}




\begin{tabular}{|c|c|c|c|}
\hline de Minas Gerais & ção Eucarístico & $\mathrm{G}$ & sarial \\
\hline $\begin{array}{c}\text { Universidade Estadual de Montes } \\
\text { Claros }\end{array}$ & Darcy Ribeiro & $\mathrm{G}$ & $\begin{array}{l}\text { Direito Mer- } \\
\text { cantil }\end{array}$ \\
\hline $\begin{array}{c}\text { Universidade Federal de Juiz de } \\
\text { Fora }\end{array}$ & $\begin{array}{l}\text { Campus Universi- } \\
\text { tário }\end{array}$ & $\mathrm{G}$ & $\begin{array}{l}\text { Direito Comer- } \\
\quad \text { cial }\end{array}$ \\
\hline $\begin{array}{l}\text { Universidade Federal de Minas } \\
\text { Gerais }\end{array}$ & Belo Horizonte & $\mathrm{G}$ & $\begin{array}{l}\text { Direito Empre- } \\
\quad \text { sarial }\end{array}$ \\
\hline $\begin{array}{l}\text { Universidade Federal de Ouro } \\
\text { Preto }\end{array}$ & Ouro Preto & $\mathrm{G}$ & $\begin{array}{l}\text { Direito Comer- } \\
\text { cial }\end{array}$ \\
\hline $\begin{array}{l}\text { Universidade Federal de Uber- } \\
\text { lândia }\end{array}$ & Santa Mônica & $\mathrm{G}$ & $\begin{array}{l}\text { Direito Empre- } \\
\text { sarial }\end{array}$ \\
\hline Universidade FUMEC & Belo Horizonte & $\mathrm{G}$ & $\begin{array}{l}\text { Direito Empre- } \\
\text { sarial }\end{array}$ \\
\hline $\begin{array}{c}\text { Fundação Universidade Federal } \\
\text { da Grande Dourados }\end{array}$ & Dourados & S & $\begin{array}{l}\text { Direito Empre- } \\
\text { sarial }\end{array}$ \\
\hline $\begin{array}{l}\text { Universidade Estadual de Mato } \\
\text { Grosso do Sul }\end{array}$ & Dourados & S & $\begin{array}{l}\text { Direito Empre- } \\
\quad \text { sarial }\end{array}$ \\
\hline $\begin{array}{c}\text { Centro Universitário do Estado } \\
\text { do Pará }\end{array}$ & $\begin{array}{l}\text { Unidade Alcindo } \\
\text { Canela }\end{array}$ & A & $\begin{array}{l}\text { Direito Empre- } \\
\quad \text { sarial }\end{array}$ \\
\hline Universidade Federal do Pará & Belém/Marabá & A & $\begin{array}{l}\text { Direito Empre- } \\
\text { sarial }\end{array}$ \\
\hline Universidade Estadual da Paraíba & $\begin{array}{l}\text { Guarabira/Campina } \\
\text { Grande }\end{array}$ & B & $\begin{array}{l}\text { Direito Empre- } \\
\text { sarial }\end{array}$ \\
\hline Universidade Federal da Paraíba & João Pessoa & $\mathrm{B}$ & $\begin{array}{l}\text { Direito Empre- } \\
\quad \text { sarial }\end{array}$ \\
\hline $\begin{array}{c}\text { Universidade Federal de Campina } \\
\text { Grande }\end{array}$ & Sousa & B & $\begin{array}{l}\text { Direito Empre- } \\
\quad \text { sarial }\end{array}$ \\
\hline $\begin{array}{l}\text { Faculdade de Ciências Sociais } \\
\text { Aplicadas de Petrolina }\end{array}$ & Petrolina & $\mathrm{E}$ & $\begin{array}{l}\text { Direito Comer- } \\
\quad \text { cial }\end{array}$ \\
\hline $\begin{array}{l}\text { Universidade Católica de Per- } \\
\text { nambuco }\end{array}$ & Recife & $\mathrm{E}$ & $\begin{array}{l}\text { Direito de Em- } \\
\text { presa }\end{array}$ \\
\hline $\begin{array}{l}\text { Universidade Federal de Pernam- } \\
\text { buco }\end{array}$ & Recife & $\mathrm{E}$ & $\begin{array}{l}\text { Direito Comer- } \\
\quad \text { cial }\end{array}$ \\
\hline $\begin{array}{l}\text { Instituto de Ciências Jurídicas e } \\
\text { Sociais Professor Camillo Filho }\end{array}$ & Teresina & I & $\begin{array}{l}\text { Direito Empre- } \\
\text { sarial }\end{array}$ \\
\hline Universidade Estadual do Piauí & $\begin{array}{c}\mathrm{Pi}- \\
\cos / \text { Teresina/Parnaíb } \\
\mathrm{a}\end{array}$ & I & $\begin{array}{l}\text { Direito Comer- } \\
\quad \text { cial }\end{array}$ \\
\hline
\end{tabular}


Universidade Federal do Piauí

Pontifícia Universidade Católica do Paraná

Universidade Estadual de Londrina

Universidade Estadual de Maringá

Universidade Estadual de Ponta Grossa

Universidade Estadual do Oeste do Paraná

Universidade Federal do Paraná

Escola de Direito do Rio de Janeiro - Direito Rio

Universidade do Estado do Rio de Janeiro

Universidade Federal do Estado do Rio de Janeiro

Universidade Federal do Rio de Janeiro

Universidade Federal Fluminense

Centro Universitário do Rio

Grande do Norte

Universidade do Estado do Rio

Grande do Norte

Universidade Federal do Rio

Grande do Norte

Universidade Federal de Rondônia

Universidade Federal de Roraima

Centro Universitário Franciscano

Fundação Universidade Federal do Rio Grande
Petrônio Portella

Unidade Sede

Londrina

Maringá

Campus Central

Francisco Beltrão

Centro Curitiba

Unidade Sede

Rio de Janeiro

Voluntários da Pátria

Faculdade de Direito Niterói

Natal

Mossoró

Natal

Cacoal/Porto Velho

Paricarana

Campus II

Rio Grande
$\mathrm{O}$

Direito Empresarial

Direito Empresarial

Direito Comercial

Direito Empresarial

Direito Comer-

R cial

Direito Comer-

R cial

Direito Empresarial

Direito Empresarial

Direito Comercial

Direito Empresarial

Direito Comercial

Direito Empresarial

Direito Empresarial

Direito Empresarial

Direito Empresarial

Direito Empresarial

Direito Comer-

R cial

Direito Empresarial

Direito Comer-

S cial 
Universidade Federal de Pelotas

Universidade Federal de Santa Maria

Universidade Federal do Rio Grande do Sul

Universidade Federal de Santa Catarina

Universidade Federal de Sergipe

Centro Universitário Uniseb

Escola de Direito de São Paulo Direito GV

Faculdade de Ciências Econômicas - FACAMP

Faculdade de Direito de Franca

Faculdade de Direito de São Bernardo do Campo

Faculdade de Direito de Sorocaba

Faculdade de Direito Professor Damásio de Jesus

Faculdades Integradas Antônio Eufrásio de Toledo

Pontifícia Universidade Católica de Campinas

Pontifícia Universidade Católica de São Paulo

Universidade de São Paulo

Universidade Estadual Paulista Júlio de Mesquita Filho

Universidade Presbiteriana Mackenzie

Universidade Federal do Tocantins
Pelotas

Santa Maria

Campus Centro

Trindade

São Cristóvão

Ribeirânia

São Paulo

Campinas

Franca

São Bernardo do

Campo

Unidade Sede

São Paulo

Presidente Pruden-

te

Campus Central

Perdizes

Unidade Sede

Franca

Higienópolis

Palmas
Direito Empresarial

Direito Empresarial

Direito Empresarial

Direito Empresarial

Direito Comercial

Direito Empresarial

Direito dos Negócios

Direito Empresarial

Direito Empresarial

Direito Comercial

Direito Empresarial

Direito Empresarial

Direito Empresarial

Direito Comercial

Direito Comercial

Direito da Empresa Direito Empresarial

Direito de Empresa Direito Comercial 
Fonte: Dados extraídos do Programa "OAB recomenda"186. In: GELLER, Rodolfo Hans et al. OAB Recomenda: indicador de educação jurídica de qualidade. 4. ed. Brasília: OAB, Conselho Federal, 2012.

Com o intuito de conhecer a preferência das Faculdades de Direito em relação ao designativo da disciplina em comento, foram observadas Grades Curriculares dos Cursos de Direito com o selo "OAB Recomenda" (Edição 2012). São contabilizados, para tal fim, 79 Cursos de Direito das mais variadas regiões brasileiras, de acordo com o tabelamento do Programa da Ordem dos Advogados do Brasil.

É interessante notar que, dos 79 cursos jurídicos analisados, a maioria utiliza, como nomenclatura, o termo Direito Empresarial (ou Direito da Empresa), somando 69,62\% dos casos. Ou seja, dos 79 Cursos de Direito, fica auferido que 55 deles preferem, para usar em suas Matrizes Curriculares, o termo Direito Empresarial ou de Empresa.

No entanto, 22 Instituições optaram pelo designativo Direito Comercial para constar no currículo de seus estudantes, dentre elas universidades tradicionais, como a UnB, a UFPE, a UEL, a PUC-SP e a UFRJ. Esses 27,84\% são números que devem ser considerados. Eles permitem a observação de que o termo Direito Comercial, mesmo não tendo a predileção das Faculdades Jurídicas (e talvez de alguns autores) na atualidade, ainda sobrevive e sustenta a sua força. Tanto é verdade que ao se discutir um novo arcabouço jurídico para reger a matéria, políticos e juristas brasileiros escolheram o nome Código Comercial, e não Código Empresarial. Trata-se dos Projetos de Lei de n. ${ }^{\circ}$ 1.572/2011 e 487/2013.

Além de Direito Empresarial e Direito Comercial, observa-se a presença de dois outros designativos, de acordo com a tabela acima. São eles: Direito Mercantil e Direito dos Negócios. O Primeiro pela Faculdade de Direito da Universidade Estadual de Montes Claros (Unimontes) ${ }^{187}$,

\footnotetext{
${ }^{186}$ Com exceção da nomenclatura das disciplinas, retiradas dos próprios sítios eletrônicos dos Cursos de Direito em tela, os outros dados foram extraídos do Programa "OAB recomenda", como esclarecido abaixo da tabela.

${ }^{187}$ Que, além das Cadeiras de "Direito Mercantil I", "Direito Mercantil II", "Direito Mercantil III" e "Direito Mercantil IV", há ainda as Cadeiras de "Direito Empresarial I", "Direito Empresarial II" e, como disciplina optativa, "Direito Econômico".
} 
e o segundo pela Escola de Direito de São Paulo, da Fundação Getúlio Vargas (Direito GV).

\section{CONSIDERAÇÕES FINAIS}

Neste trabalho, buscou-se, à luz da História do Comércio e do Direito Comercial, mostrar que durante todo esse período, que vai do desenvolvimento do Comércio com o surgimento de algumas normas (na Idade Antiga), passando pelo advento efetivo do Direito Comercial (ainda na Idade Média), até meados do século XX, quando perde força a Teoria dos Atos de Comércio, sendo geralmente "sucedida" pela Teoria da Empresa, o designativo Direito Comercial seria o mais adequado a ser empregado (como sucessor do Direito Mercantil).

No entanto, já no século XX (a partir da década de 40), quando conquista destaque a Teoria da Empresa, cunhada pela doutrina comercialista italiana, e positivada em diploma legislativo pelo governo fascista de Mussolini, observa-se uma mudança de panorama. A partir de então, a nomenclatura Direito Empresarial ganha força e, no entendimento de alguns, deveria até mesmo "suceder" o designativo tradicional (Direito Comercial).

Essa situação levou a um debate em relação à adequabilidade dos termos: Qual seria, então, o mais adequado? Direito Comercial, designativo quase milenar e, portanto, mais tradicional e já enraizado, que foi legitimado com o passar do tempo; ou Direito Empresarial, que surge, conforme alguns apregoam, como uma nova roupagem do Direito Comercial, principalmente em função da valorização da Empresa e do Empresário nos Códigos hodiernos (Inclusive o Código Civil brasileiro de 2002)?

A análise deste trabalho bebericou das opiniões de juscomercialistas/empresarialistas consagrados, bem como levou em consideração as grades curriculares dos Cursos de Direito brasileiros, sob o recorte dos detentores do "Selo OAB Recomenda" (Edição de 2012), sem, no entanto, se vincular aos seus resultados, que é de ordem meramente quantitativa. Em relação ao pensamento dos "doutores", pôde-se observar a existência de uma dualidade de opiniões, levando, desta forma, a um equilíbrio quantitativo; muito embora os argumentos dos defensores do termo "Direito Comercial" sejam mais consentâneos à luz tanto do 
historicismo jurídico quanto do atual ordenamento jurídico positivo brasileiro, sob olhar sistêmico.

Vários são os estudiosos do Direito Comercial/Empresarial que entendem ser o termo Direito Empresarial o designativo mais adequado para se utilizar como nomenclatura do Direito Privado em tela (principalmente baseando-se na Teoria da Empresa).

Muitos também são os pensadores que entendem ser o termo Direito Comercial o mais adequado para se usar, mesmo na atualidade. Eles argumentam que além de sua tradicionalidade, a Constituição da República Federativa do Brasil, de 05 de outubro de 1988, optou por trazer em seu texto constitucional o termo Direito Comercial (art. 22, I, da CRFB/1988), o que é um argumento a fortiori ratione, principalmente para quem supervaloriza o Direito Positivo. O fato de os Projetos de Lei de n. ${ }^{\circ} 1.572 / 2011$ e 487/2013, em tramitação no Congresso Nacional, que visam a instituir um novo código de direito comercial brasileiro, optarem por essa denominação; aliada à douta opinião de que seja "Direito Empresarial" gênero que englobe o "Direito Comercial" como espécie, também se inserem como teses de sobrepeso, que pendem as mais argutas opiniões a este pensar.

Além do pensamento dos jus-empresarialistas, procurou-se, ademais, observar as matrizes curriculares dos Cursos Jurídicos com o selo "OAB Recomenda" (Edição 2012). Não obstante quase setenta por cento optarem pelo designativo Direito Empresarial, um número considerável mostrou que o termo Direito Comercial ainda sobrevive, robusto.

Em síntese, partindo dos dados extraídos das grades curriculares e, ainda, das opiniões observadas, pode-se concluir, concordando com Mamede $^{188}$, Coelho ${ }^{189}$, Sharp Júnior ${ }^{190}$ e Negrão ${ }^{191}$, que as duas nomenclaturas vêm sendo aceitas. Loria, citado por Corrêa ${ }^{192}$, tratando da questão da nomenclatura no âmbito das Ciências Econômicas, acentua "que é

\footnotetext{
${ }^{188}$ MAMEDE, Gladston. Direito Empresarial brasileiro: empresa e atuação empresarial, volume 1. 7. ed. São Paulo: Atlas, 2013.

189 COELHO, Fábio Ulhoa. Manual de Direito Comercial: Direito de Empresa. São Paulo: Saraiva, 2010.

190 SHARP JÚNIOR, Ronald Amaral. Direito Comercial e de Empresa. Rio de Janeiro: Elsevier, 2009.

${ }^{191}$ NEGRÃO, Ricardo. Manual de Direito Comercial e de Empresa. 10. ed. São Paulo: Saraiva, 2013.

192 CORRÊA, Oscar Dias. Economia Política - Introdução e Conceitos Fundamentais. Belo Horizonte: Santa Maria, 1951.
} 
inútil demorar-se na escolha de um nome para a Economia, porque não é o rótulo que interessa, mas a substância; ou, como diz Tosi, não é a etiqueta que faz o vinho".

E Corrêa estende a problemática para outras áreas científicas (entre elas, a Ciência Jurídica):

Tanto mais quanto em todas as ciências poder-seiam encontrar discordâncias entre nome e conteúdo, dado que o nome é antigo, e se mantém, enquanto o conteúdo varia, a todo momento, com as novas aquisições e as constantes flutuações da doutrina. ${ }^{193}$

Corrêa chama, ainda, à prevenção quanto às dificuldades da nomenclatura, "com que luta, sobretudo, o analista das ciências sociais", pois "cada palavra tem sentido próprio, a que, entretanto, cada autor confere peculiaridades estranhas, que lhe complicam o entendimento, quando não o perturbam" ${ }^{194:}$

Mesmo porque, conforme salienta Villey ${ }^{195}$, "o que governa o sentido das palavras é o uso, ainda que caiba, por vezes, aos sábios orientá-lo e dirigi-lo prudentemente".

Mas é verdade que, diz Corrêa ${ }^{196}$, "ora se incide no mal do tecnicismo, ora no desejo de originalidade a qualquer preço, ora se confunde pela ocorrência de palavras tomadas à linguagem comum, e que têm, no conhecimento científico, noção diversa".

Ainda que a maioria dos cursos jurídicos analisados (os detentores da edição de 2012 do Programa "Selo OAB Recomenda") aponte para a terminologia "Direito Empresarial", é imperioso constar que a tiragem auferida é de apenas 79 Cursos de Direito, de um universo de quase 1260 existentes no Brasil. Além de que tal aporte é meramente quantitativo, à medida que as faculdades de Direito comumente elegem o nome para a Cadeira inspiradas em razões didáticas, muitas das vezes inclusive escolhidos pela coordenação do curso ou diretoria da faculdade (por professo-

193 CORRÊA, Oscar Dias. Economia Política - Introdução e Conceitos Fundamentais. Belo Horizonte: Santa Maria, 1951. p. 10.

${ }^{194}$ Idem. p. 13

195 CORRÊA, Oscar Dias. Ciência, Teoria e Doutrina Econômica. Revista da Faculdade de Direito da UFMG. v. 4, 1952. p. 67.

${ }^{196}$ Idem. p. 56-57. 
res que nem sequer sejam comercialistas), o que implica em dizer que não necessariamente reflete essa adoção pela consagração doutrinária desse termo.

Ex positis, este trabalho se posiciona pelo termo Direito Comercial como o mais adequado para se usar, mesmo na atualidade. As razões se embasam pelo que se passa a expor, sumularmente:

I) Sua tradicionalidade, concordando-se com o entendimento desposado por Corrêa, para quem:

"em todas as ciências poder-se-iam encontrar discordâncias entre nome e conteúdo, dado que o nome é antigo, e se mantém, enquanto o conteúdo varia, a todo momento, com as novas aquisições e as constantes flutuações da doutrina". ${ }^{197}$

II) Interpretação sistemática com o ordenamento jurídico positivo, tendo em vista que a Constituição da República Federativa do Brasil, de 05 de outubro de 1988, optou por trazer em seu texto constitucional o termo Direito Comercial (art. 22, I, CRFB/1988), o que é um argumento a fortiori ratione; bem como o fato de os Projetos de Lei de n. ${ }^{\circ}$ 1.572/2011 e 487/2013, em tramitação no Congresso Nacional, que visam a instituir um novo código de direito comercial brasileiro, optarem por essa denominação;

III) $\mathrm{O}$ fato de o criador da teoria da empresa, Cesare Vivante, ter abrido mão de seu posicionamento ante os argumentos de Alfredo Rocco, inclusive aceitando ser nomeado para presidir Comissão Elaboradora de projeto de novo Código Comercial italiano; bem como a utilização da Teoria da Empresa e da unificação do direito privado em um mesmo diploma legislativo pelo Governo Fascista italiano do ditador Benito Mussolini (1942), com a finalidade ideológica de promover seus objetivos escusos; e, nessa esteira, o ítalo-brasileiro fascista Miguel Reale ter incorporado a teoria de empresa no projeto de novo código civil (1975) a partir do diploma congênere italiano, isso em pleno regime militar (década de 1970), de modo que o projeto, ao ser promulgado (2002), já se encontrava caduco, vez que já estava defasado em quase três déca-

197 CORRÊA, Oscar Dias. Economia Política - Introdução e Conceitos Fundamentais. Belo Horizonte: Santa Maria, 1951. p. 10. 
das, não estando em consonância com a Constituição da República Federativa do Brasil, de 05 de outubro de 1988, que além de instituir um Estado Democrático de Direito (incompatível, por conseguinte, tanto com o Regime totalitário fascista, quanto com a ordem ab-rogada do regime de segurança que a precedeu), denomina expressamente esse ramo jurídico como "direito comercial" (art. 22, I, CRFB/1988);

IV) E, ainda, em consonância às doutas opiniões (com as quais concordamos), arguidas sobretudo por Castro Júnior ${ }^{198}$, Bottallo ${ }^{199}$ e Barbosa ${ }^{200}$, de que seja "Direito Empresarial" gênero que englobe o "Direito Comercial" como espécie, de modo que o ramo jurídico em comento se trate de "Direito Comercial", que também é matéria de um ramo jurídico ainda maior, denominado "Direito Empresarial", que dialoga, para além (evidentemente) do Direito Comercial, com os Direitos Econômico, Tributário, Trabalhista, Consumerista, das Marcas e das Patentes e Obrigacional/Contratual (ramos estes do Direito Civil que, nas relações empresariais, adquirem contornos próprios), entre outros.

Se a Constituição de 1988 outorgou competência para a União legislar privativamente sobre "direito comercial" (art. 22, I) e o Código Civil de 2002 trata sobre "Direito de Empresa" (Livro II), além de revogar expressamente a Parte Primeira do Código Comercial de 1850 (art. 2045), isso quer dizer que estamos num limbo jurídico de normas comerciais? E, não sendo competência privativa da União legislar sobre "direito empresarial" mas sim sobre "direito comercial", isso implica em dizer que podem os Estados-membros legislar sobre esse assunto? Evidentemente que não!

Pelo art. 22, I, da CRFB/1988, tanto direito comercial, quanto direito civil (donde as normas do Direito Obrigacional e do Direito Contratual, dentre outras aplicáveis às relações empresariais) e direito do trabalho (além de direito agrário) são competências legislativas privativas da União, como também a propaganda comercial (art. 22, XXIX); sendo

\footnotetext{
198 CASTRO JÚNIOR, Armindo. Direito Comercial ou Direito Empresarial?: breves colocações acerca dessa hodierna discussão. Cuiabá (MT): Universidade de Cuiabá, 2014. (Palestra).

199 BOTTAllo, Eduardo Domingos (Org.). Curso de Direito Empresarial: Direito Comercial. Volume I. São Paulo: Editora Resenha Tributária; Editora da Universidade Católica, 1976.

200 BARBOSA, Washington. Direito Empresarial Versus Direito Comercial. Disponível em: < http://www.juristas.com.br/informacao/artigos/direito-empresarialversus-direito-comercial/154/ >. Acessado em 29.12.2014.
} 
competência concorrente entre a União, os Estados-membros e o Distrito Federal legislarem sobre direito tributário e direito econômico (art. 24, I), juntas comerciais (art. 22, III), produção e consumo (art. 24, V) e responsabilidade por dano ao consumidor (art. 24, VIII).

Esse modo, exsurge da diagnose do fato constitucional, que direito comercial (competência legislativa privativa da União) é matéria diversa do direito empresarial (cujas disciplinas são em parte competência legislativa privativa da União, e em parte competência legislativa concorrente da União, dos Estados-membros e do Distrito Federal), com ele não se confundindo, embora seja ramo que o integre.

Um determinado autor ou leitor pode até ter a sua preferência, mas terá de respeitar e entender quando vier, em algum escrito, o outro termo. Assim, tanto Direito Empresarial, como Direito Comercial (além de Direito Mercantil ou dos Negócios/Negocial) vêm sendo utilizados, como que se referissem ao mesmo ramo do Direito; a opção por um, ou por outro, acarreta atualmente em apenas uma diferença terminológica, que se pretende não incidir em maiores consequências.

Entretanto, por todo o exposto, conclui-se que, conforme a melhor técnica, embora a difusão desenfreada do senso comum jurídico que pretende ao chamamento do ramo jurídico em questão de "Direito Empresarial", é o mais correto se referir a este direito privado como "Direito Comercial", em consonância com a história do Direito e com a tradição (que é, inclusive, fonte interpretativa e integrativa do Direito, conforme o art. $4^{\circ}$ do Decreto-Lei de $n^{\circ} 4.657$, de 4 de setembro de 1942, que, conforme a redação dada pela Lei de $\mathrm{n}^{\circ}$ 12.376, de 30 de dezembro de 2010, à sua ementa, institui a "Lei de Introdução às normas do Direito Brasileiro"), com a interpretação sistemática do ordenamento jurídico pátrio (sobretudo a partir da dicção do art. 22, I, da CRFB/1988) e com a demonstração pela qual existem tanto o Direito Comercial quanto o Direito Empresarial, sendo porém aquele um ramo deste.

\section{REFERÊNCIAS BIBLIOGRÁFICAS}

ARNOULDI, Paulo Roberto Colombo. Teoria Geral do Direito Comercial: introdução à teoria da empresa. São Paulo: Saraiva, 1998. 
AZEVEDO, Antonio Junqueira de. O Direito Pós-Moderno e a Codificação. In: Revista de Direito do Consumidor. Vol. 33. Jan/2000. São Paulo: Revista dos Tribunais. Acesso em: 07 jun. 2012 , p. 05.

BARBOSA, Washington. Direito Empresarial Versus Direito Comercial. Disponível em: < http://www.juristas.com.br/informacao/artigos/direitoempresarial-versus-direito-comercial/154/ >. Acessado em 29.12.2014.

BERTOLDI, Marcelo M.; RIBEIRO, Marcia Carla Pereira. Curso Avançado de Direito Comercial. São Paulo: Revista dos Tribunais, 2006.

BOTTALlO, Eduardo Domingos (Org.). Curso de Direito Empresarial: Direito Econômico. Volume III. São Paulo: Editora Resenha Tributária; Editora da Universidade Católica, 1976.

BRAZ, Petrônio. Direito Municipal na Constituição. 6 ed. Leme/SP: J. H. Mizuno, 2006.

BRAZ, Petrônio. Tratado de Direito Municipal - Volume III: Sistema Tributário Municipal e Responsabilidade Fiscal. $2^{\mathrm{a}}$ edição. Leme/SP: Mundo Jurídico, 2007.

BUlGARELlI, Waldirio. Direito Comercial. 13. ed. ed. São Paulo: Atlas, 1998.

CARVALHO DE MENDONÇA, José Xavier. Tratado de Direito Comercial Brasileiro. 1ed. atualizada por Ricardo Negrão. Campinas: Bookseller, 2000.

CASTRO JÚNIOR, Armindo. Direito Comercial ou Direito Empresarial?: breves colocações acerca dessa hodierna discussão. Cuiabá (MT): Universidade de Cuiabá, 2014. (Palestra).

CAVAlli, Cássio Machado. A Evolução Histórica do Direito Comercial: do Particularismo Medieval ao Microssistema Constitucionalizado. Dissertação de Mestrado, Porto Alegre, PUCRS, 2006.

COELHO, Fábio Ulhoa. Curso de Direito Comercial. Volume 1. São Paulo: Saraiva, 2008.

COELHO, Fábio Ulhoa. Manual de Direito Comercial: Direito de Empresa. São Paulo: Saraiva, 2010.

COMETTI, Marcelo Tadeu. Empresário e Comerciante - Direito Empresarial e Direito Comercial: apenas uma diferença 
terminológica? Disponível em: < http://www.migalhas.com.br $>$. Acessado em 21 de Abril de 2014.

CORREAA, Oscar Dias. Ciência, Teoria e Doutrina Econômica. Revista da Faculdade de Direito da UFMG. v. 4, 1952.

CORRÊA, Oscar Dias. Economia Política - Introdução e Conceitos Fundamentais. Belo Horizonte: Santa Maria, 1951.

CORRÊA, Oscar Dias. Introdução Crítica à Economia Política. Belo Horizonte: Santa Maria, 1957.

CORRÊA, Oscar Dias. O sistema político-econômico do futuro: o societarismo. Rio de Janeiro: Forense Universitária, 1994.

FAZZIO JÚNIOR, Waldo. Manual de Direito Comercial. 8. ed. São Paulo: Atlas, 2007.

FERNANDES, Jean Carlos. Direito Empresarial Aplicado. Belo Horizonte: Del Rey, 2007.

FÜHRER, Maximilianus Cláudio Américo. Resumo de Direito Comercial. São Paulo: Malheiros Editores, 2004.

FURQUIM, Maria Célia de Araújo. A Cooperativa como alternativa de trabalho. São Paulo: LTr, 2001.

GELLER, Rodolfo Hans et al. OAB Recomenda: indicador de educação jurídica de qualidade. 4. ed. Brasília: OAB, Conselho Federal, 2012.

HUBERMAN, Leo. História da Riqueza do Homem. 16 ed.. Disponível em: < http://www.controversia.com.br/antigo/uploaded/pdf/16574 _huberman-historia-da-riqueza-do-homem.pdf. >. Acessado em 20.09.2015. Tradução por Waltensir Dutra.

MALUF, Sahid. Teoria Geral do Estado. 25 ed. atual. / pelo Prof. Miguel Alfredo Malufe Neto. São Paulo: Saraiva, 1999.

MAMEDE, Gladston. Direito Empresarial brasileiro: empresa e atuação empresarial, volume 1. 7. ed. São Paulo: Atlas, 2013.

MENDONÇA, Jacy de Souza. Introdução ao Estudo do Direito. São Paulo: Rideel, 2010.

MÜSSNICH, Francisco Antunes Maciel. A quem interessa um novo código comercial?. Revista RI, fevereiro de 2014, p. 42-46. Disponível em:

http://www.abrasca.org.br/Uploads/autoregulacao/RI180_For um_Abrasca_a_quem_Interessa_Novo_Codigo_Comercial.p df $>$. Acessado em 29.12.2014.

NEGRÃO, Ricardo. Manual de Direito Comercial e de Empresa. 10. ed. São Paulo: Saraiva, 2013. 
RAMOS, André Luiz Santa Cruz. Curso de Direito Empresarial: o novo regime jurídico-empresarial brasileiro. Salvador: JusPodivm, 2009.

RAMOS, André Luiz Santa Cruz. Direito Comercial ou Direito Empresarial?: Notas sobre a Evolução Histórica do Ius Mercatorum. In: Revista Síntese de Direito Civil e Processual Civil, v. 7, 2006.

REALE, Miguel. Lições preliminares de Direito. 27. ed. São Paulo: Saraiva, 2004.

REIS, Jair Teixeira dos. História do Trabalho e seu conceito. In: Revista Eletrônica de Direito do Centro Universitário Newton Paiva, número 6, 2005.

REIS, Jair Teixeira dos. Manual de Direito Empresarial: noções gerais de Direito. São Paulo: RCS Editora, 2006.

REIS, Jair Teixeira dos. Manual Jurídico do Empresário. São Paulo: IOB, 2007.

REQUIÃO, Rubens. Curso de Direito Comercial. São Paulo: Saraiva, 2007.

RODRIGUES, Frederico Viana. Autonomia do Direito de Empresa no Novo Código Civil. In: RODRIGUES, Frederico Viana (Org.). Direito de Empresa no Novo Código Civil. Rio de Janeiro: Forense, 2004.

SHARP JÚNIOR, Ronald Amaral. Direito Comercial e de Empresa. Rio de Janeiro: Elsevier, 2009.

SOUZA, Nadialice Francischini de. Direito Empresarial: muito além do Direito Comercial. Disponível em: < http://revistadireito.com/direito-empresarial-muito-alem-dodireito-comercial/ > . Acessado em 21 de Abril de 2014.

TEPEDINO, Gustavo. O Código Civil, os microssistemas e Constituição: premissas para uma reforma legislativa. Acesso em: 30 mar. 2010.

VELOSO, Waldir de Pinho. Essência do direito comercial. Montes Claros: Unimontes, 2001. 
